\title{
Empirical Testing of the APT Model with Pre-Specifying the Factors in the Case of Romanian Stock Market
}

\section{Florin Dan Pieleanu}

Doctoral student in Finance, Bucharest Academy of Economic Studies, Romania.

*Corresponding Author: E-mail: florin.dan.pieleanu@gmail.com

\begin{abstract}
Since the discovery and the development of the financial equilibrium asset pricing models, they were constantly and repeatedly tested mainly for the big markets and scarcely for the smaller or the emerging ones. Romania belongs to the last category, hence empirical testing of these models for its case was almost inexistent. So, this paper examines the validity and the applicability of the Arbitrage Pricing Theory model for the Romanian stock exchange, conditioned of course by the available data. The data used is represented by monthly returns of 60 companies, listed on the Bucharest Stock Exchange, using a 6-year period, from 01.01.2005 to 31.12.2010. The pre-specifying of possible economic factors method was implied, using a total of 16 economical variables, among which some were used also in the more famous studies, and the rest were added. The obtained results show as significant for influencing assets' return a number of 46 variables with respect to the testing approach, but of course the conclusions can be subdued to potential errors, they are not exhaustive and can surely be improved.
\end{abstract}

Keywords: APT, Bucharest stock exchange, Factor loadings, Multiple regressions, Pre-specifying factors.

\section{Introduction}

\section{JEL Classification: C31, G12}

The present paper is organized as follows: sections 1 and 2 introduce the APT model and resume its development; section 3 summarizes the concerns in the field and some of the empirical studies conducted through time; section 4 contains the actual testing of the model on the Romanian market, including the descriptions of used database, methodology and obtained results, along with their interpretations; section 5 resumes the conclusions and outlines some obvious limitations; section 6 presents the references used during the analysis; section 7 presents the annexes.

\section{Arbitrage Pricing Theory}

Formulated by S. Ross [1] in 1976, offers a testable alternative to CAPM, trying to improve some of the latter's disadvantages. Whereas CAPM states that the security rates of return will be linearly related to a single common factor, which is the rate of return of the market portfolio, APT is more general, predicting that the rate of return on a stock is a linear function of different multiple factors. Hence:
$\mathrm{R}_{\mathrm{i}}=\mathrm{E}\left(\mathrm{R}_{\mathrm{i}}\right)+\mathrm{b}_{\mathrm{i} 1} \times \mathrm{F}_{1}+\mathrm{b}_{\mathrm{i} 2} \times \mathrm{F}_{2}+\ldots \ldots \ldots .+\mathrm{b}_{\mathrm{ik}} \times \mathrm{F}_{\mathrm{k}}+\varepsilon_{\mathrm{I}}$

where: $\mathrm{R}_{\mathrm{i}}=$ the random rate of return on the "i"th asset; $\mathrm{E}\left(\mathrm{R}_{\mathrm{i}}\right)=$ the expected rate of return on the "i"th asset; $b_{i k}=$ the sensitivity of the "i"th asset's return to the $F_{k}$ factor; $F_{k}=$ the " $k$ "th factor common to the returns of all considered assets, having mean zero, representing the systematic risk of the "i"th asset; $\varepsilon_{i}=$ a random zero mean noise term for the "i"th asset. In matrix form: $R_{\mathrm{i}}=\mathrm{E}\left(\mathrm{R}_{\mathrm{i}}\right)+$ $\mathrm{B} \times \mathrm{F}+\varepsilon_{i}$, Where: $\mathrm{B}=$ the matrix of sensitivities $\mathrm{b}_{\mathrm{i} 1}$, $b_{i 2}, \ldots, b_{i k} ; F=$ the matrix of all factors considered, presumable to influence assets' returns. As it can be seen, CAPM can be regarded as a special case of the APT, with the market rate of return being the single relevant factor. APT is developed with classical hypothesis: a frictionless and perfect competitive market, where the agents have homogeneous expectations that the random returns of more assets will follow the multi-factorial model given by equation (1). Additionally, the number $n$ of considered assets must be greater than the factor number, $k$. 


\section{Available online at www.managementjournal.info}

\section{Theoretical and Mathematical Development}

In this section, aspects from Copeland and Weston [2] or Mishkin [3] will be used. The development of APT begins with equation (1) and has its base on the following idea: in equilibrium, all portfolios than can be selected from the set of assets under consideration and that satisfy the conditions.

- without additional wealth invested

- without any risk involved

must not earn a return on average. These portfolios are called arbitrage portfolios, and they will be made so: let $\mathrm{w}_{\mathrm{i}}$ be the change of sum invested in the "i"th asset, as a percentage of an individual's total invested wealth, aiming to modify the proportions of the stocks in his/her portfolio. In order to obtain an arbitrage portfolio that requires no change in wealth (deposit or withdrawal), the logical action will be selling some assets and then buying others using the gained sum. Mathematically, the zero change in wealth is written as:

$\sum_{i=1}^{n} w i=0$

If there are $\mathrm{n}$ assets in the arbitrage portfolio, then the additional return gained by modifying the proportions of the included assets is:

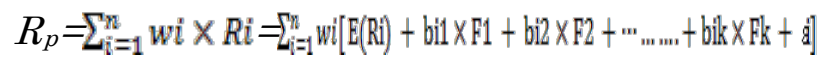
so:

$R_{p}=\sum_{i=1}^{n} w i \times E(R i)+\sum_{i=1}^{n} w i \times F 1 \times b i 1+. .+\sum_{i=1}^{n} w i \times F k \times b i k+\sum_{i=1}^{n} w i \times \varepsilon i(3)$

For obtaining a riskless arbitrage portfolio, it is necessary to eliminate both types of risk, systematic (non-diversifiable) and unsystematic (diversifiable, idiosyncratic). This can be done by meeting the following conditions: (4)

- The arbitrage portfolio being well-diversified; in other words " $n$ " must be a large number

- The percentage changes in each asset' $s$ investment must be small and approximating $1 / \mathrm{n}: \mathrm{Wi} \approx 1 / \mathrm{n}$

- Choosing changes $\mathrm{w}_{\mathrm{i}}$ in such a manner that for each factor " $k$ " no systematic risk exists; in other words the weighted sum of the systematic risk components $b_{k}$ to be zero:

$\sum_{i=1}^{n} w i \times b i k=0$

Because the error terms $\varepsilon_{i}$ are independent and " $n$ " is a big numbers, the law of large numbers ensures that $\sum_{i=1}^{n}$ wi $\times$ si approaches zero, hence the last term of equation (3) will disappear, which is equivalent to the disappearance of the idiosyncratic risk. Now the equation takes this form:

$R_{p}=\sum_{i=1}^{n}$ wi $\times E(R i)+\sum_{i=1}^{n} w i \times F 1 \times b i 1+. .+\sum_{i=1}^{n}$ wi $\times$ Fk $\times$ bik

Since the systematic risk doesn't exist as well (by 4.iii), all the terms besides the first one disappear from equation (4), and such a arbitrage portfolio without both types of risks becomes possible, having a return equal to:

$\mathrm{R}_{\mathrm{p}}=\sum_{i=1}^{n} w i \times E(R i)$

But no portfolio is an equilibrium portfolio if its return can be improved without taking an additional risk and without an additional sum invested; and since the analyzed portfolio didn't imply any of them, it is necessary that:

$\mathrm{R}_{\mathrm{p}}=\sum_{i=1}^{n} w i \times E(R i)=0$

Equations (2), (4.iii) and (6) are confirmed also by linear algebra elements: any vector $\mathrm{wi}_{\mathrm{i}}(\mathrm{i}=1 . . . \mathrm{n})$ that is orthogonal to the constant vector "e", that is:

$\left(\sum_{i=1}^{n} w i\right) \times \mathrm{e}=0$, and also orthogonal to each of the coefficient $b_{k}(k=1 \ldots n)$, that is: $\sum_{i=1}^{n} w i \times b_{i k}=0$, (for each $\mathrm{k}$ )must be orthogonal to the vector of expected returns, so: $\sum_{i=1}^{n} w i \times \mathrm{E}\left(\mathrm{R}_{\mathrm{i}}\right)=0$

The algebraic consequence of this is that the expected return vector must be a linear combination of the constant vector and the coefficient vectors. Mathematically, it is necessary that a set of coefficients $\lambda_{0}, \lambda_{1} \ldots . \lambda_{\mathrm{k}}$ (in a number of " $k+1$ ") exists, such that:

$\mathrm{E}\left(\mathrm{R}_{\mathrm{i}}\right)=\lambda_{0}+\lambda_{1} \times \mathrm{b}_{\mathrm{i} 1}+\lambda_{2} \times \mathrm{b}_{\mathrm{i} 2}+\ldots \ldots .+\lambda_{\mathrm{k}} \times \mathrm{b}_{\mathrm{ik}}$

, where $b_{i k}$ is the sensitivity of the "i"th asset's return to the $\mathrm{F}_{\mathrm{k}}$ factor.If a riskless asset is available on the market, it will offer a riskless return $R_{\mathrm{f}}$ and so: $\mathrm{b}_{0 \mathrm{k}}=0$ and $\mathrm{R}_{\mathrm{f}}=\lambda_{0}$, So equation (7) can be rewritten in "excess returns form" as:

$\mathrm{E}\left(\mathrm{R}_{\mathrm{i}}\right)-\mathrm{R}_{\mathrm{f}}=\lambda_{1} \times \mathrm{b}_{\mathrm{i} 1}+\lambda_{2} \times \mathrm{b}_{\mathrm{i} 2}+\ldots \ldots .+\lambda_{\mathrm{k}} \times \mathrm{b}_{\mathrm{ik}}$

In equilibrium, all assets must fall on the arbitrage pricing line. $\quad \lambda_{1} \ldots \lambda_{\mathrm{k}}$ represent "risk premiums"(prices of the risk) in equilibrium, being defined as the difference between the expected returns of a portfolio with maximum sensitivity to factor $1,2 \ldots \mathrm{k}$ and zero sensitivity to the other factors, and the riskless rate of interest:

$\lambda_{1}=\mathrm{E}\left(\mathrm{F}_{1}\right)-\mathrm{R}_{\mathrm{f}}$ 
$\lambda_{2}=\mathrm{E}\left(\mathrm{F}_{2}\right)-\mathrm{R}_{\mathrm{f}}$

$\lambda_{\mathrm{k}}=\mathrm{E}\left(\mathrm{F}_{\mathrm{k}}\right)-\mathrm{R}_{\mathrm{f}}$

Hence, the APT form can also have the following expression:

$\mathrm{E}\left(\mathrm{R}_{\mathrm{i}}\right)-\mathrm{Rf}=\left[\mathrm{E}\left(\mathrm{F}_{1}\right)-\mathrm{R}_{\mathrm{f}}\right] \times \mathrm{b}_{\mathrm{i} 1}+\left[\mathrm{E}\left(\mathrm{F}_{2}\right)-\mathrm{R}_{\mathrm{f}}\right] \times \mathrm{b}_{\mathrm{i} 2}+\ldots \ldots .+$ $\left[\mathrm{E}\left(\mathrm{F}_{\mathrm{k}}\right)-\mathrm{R}_{\mathrm{f}}\right] \times \mathrm{b}_{\mathrm{ik}}$

(9)

or:

$\mathrm{E}\left(\mathrm{R}_{\mathrm{i}}\right)=\mathrm{Rf}+\left[\mathrm{E}\left(\mathrm{F}_{1}\right)-\mathrm{R}_{\mathrm{f}}\right] \times \mathrm{b}_{\mathrm{i} 1}+\left[\mathrm{E}\left(\mathrm{F}_{2}\right)-\mathrm{R}_{\mathrm{f}}\right] \times \mathrm{b}_{\mathrm{i} 2}+\ldots \ldots .+$ $\left[E\left(F_{k}\right)-R_{f}\right] \times b_{i k}$, and $b_{i k}$ are defined in a similar way as $B$ from CAPM, like: $b_{i k}=$ $\operatorname{cov}\left(\mathrm{R}_{\mathrm{i}}, \mathrm{F}_{\mathrm{k}}\right) / \operatorname{var}\left(\mathrm{F}_{\mathrm{k}}\right)$, where:

$\operatorname{cov}\left(\mathrm{R}_{\mathrm{i}}, \mathrm{F}_{\mathrm{k}}\right)=$ the covariance between the "i"th asset's returns and the linear transformation of the " $k$ "th factor; $\operatorname{var}\left(F_{k}\right)=$ the variance of the linear transformation of the "k"th factor.

\section{Concerns and Empirical Tests along Time}

One of the most used methods to test APT and mentioned pretty much in literature is prespecifying some economical variables as possible factors, followed by the actual testing of those in order to see if they really influence assets' returns. This method was introduced and firstly used by Chen, Roll, Ross [4]. They used 7 macro-economic and financial variables and found as being relevant the following: unanticipated inflation, term structure of interest rates, an index of industrial productions and default premium. Some of the later studies used those variables as well, adding more that were believed to have influence, with respect to the market on which the analysis was made. Among other tests known by the author and realized along time are: Virtanen and Yli-Olli [5] found as relevant actual and unanticipated inflation, long term interest rates and economical real activity; Wahlroos and Berglund [6] or Asprem [7] concluded that expected inflation is an influencing variable; Viskari [8] found that the change in money supply, Loflund [9] doing the same with the exchange rates. Clare and Thomas [10], Beenstock and Chan[11], Groenewold and Fraser[12] found that inflation is relevant for stock markets in Great Britain, Australia and USA. Cagnetti[13] concluded that the national stock market index and import level are relevant for the Italian market. Iqbal and Haider [14] found as having influence the following: unanticipated inflation, dividend yield and the index of the national stock market. The only study conducted so far on the Romanian market (as far as the author knows) about testing APT was realized by F.Bîlbîie, A.Gherman and M.Tureatcă[15]. The used data included 2 different groups of assets: for the first one 9 stocks with 343 observations from the 16 June 1997-20 November 1998 interval were used, the observations being daily prices of the stocks with the highest capitalization on BVB; for the second one, 11 stocks listed on RASDAQ market were used, with 394 daily observations from the 27 March 1997-20 November 1998 interval, with highest liquidity being the chosen criteria. The missing observations were completed by an interpolation process. The results of this research indicated the existence of minimum 2 relevant factors for BVB stocks and minimum 3 factors relevant for RASDAQ stocks. But in the same time they left room for future studies.

\section{Empirical Testing on the Romanian Market}

\section{The Database Used for Testing}

The current study is based on monthly returns for stocks listed on the Bucharest Stock Exchange during the 01.01.2005 - 31.12.2010 interval, with respect to the available information. Logarithmical values are used to ensure the series' stationarity. The data was obtained from the web pages of BVB ${ }^{1}$ and of "Kmarket" ${ }^{2}$ investment firm. The missing observations were completed with interpolation. All the stock market's categories are taken into account (I,II şi III), and they include 76 assets having available data, and from those, some are eliminated. The time period. Hence the final sample consists of 60 assets, each of them with 72 observations of monthly return (12 months for 6 years). The table 1 shows the name, the listing category and the code of the stocks included in the sample: For a proxy of the riskless interest rate, the government bonds were used, with respect to the available data. This rate had an annual value of $8.8404 \%$ in the 01.01 .2005 - 31.12.2010 period, equaling an average monthly value of $0,7367 \%$. The data was obtained from the monthly reports of BNR, on its web site ${ }^{3}$.In this study, 16 economic variables were chosen; among them 7 are the ones used in Chen, Roll and Ross' research: industrial production index, unanticipated inflation, a relevant index for the national stock market, oil price on the international market, growth of real consumption, default risk premium and the term structure of interest rates; the other added ones are: the exchange rates between national currency and 2 important foreign currencies, M1 money

\footnotetext{
${ }^{1}$ http://www.bvb.ro

2 http://www.kmarket.ro

${ }^{3}$ www.bnr.ro
} 
supply, GDP(gross domestic product) index, average interest on deposits in national currency, real rate of interest, consumer price index and the evolution of 2 relevant indexes of foreign stock markets. The summary of the variables is shown in the table 2.The internal data were obtained from monthly and annually reports of BNR and from the web site of National Institute of Statistics. The external ones were obtained from Datastream and Yahoo Finance. For series' stationary and for obtaining the unanticipated component of the variables; the first difference of the logarithmical value of them was used. Chen, Roll, Ross and many other later studies used also the unanticipated component of the analyzed variables. For variables calculated like a difference between otherseries (DP, TSIR, RIR), the transformation is not necessary since the difference itself ensures directly the unanticipated component. Below is the way how variables were calculated for testing.It can be observed that the variables can be considered uncorrelated, with a few normal exceptions, like the correlations between the stock market indexes (BET-C with FTSE and with S\&P500) and marginally the consumption growth with inflation rate and with consumption price index.

\section{Methodology, testing results and their interpretations}

Microsoft Excel and SPSS software will be used. For a determination of the number of factors with influence and for getting their "factor loadings" in SPSS, "principal component analysis" method was implied, followed by a "orthogonal varimax" rotation.

Testing will be made through 2 different approaches:

(A) The first one is the one used by Fama and Mac Beth, taken later by Chen, Roll and Ross for their study. This approach implies the following sequence of steps:

Collecting data for each of the chosen variables related to the chosen interval of time;

- Calculation of the unanticipated component for the variable time series;

- Estimating sensitivity coefficients $\left(b_{i 1} \ldots b_{i k}\right)$ of the stocks, with respect to the unanticipated components obtained in the previous step;
- Using the estimated sensitivity coefficients in order to explain the stocks' returns by implying a "cross-section" regression:

$\mathrm{R}_{\mathrm{i}}=\lambda_{0}+\lambda_{1} \times \mathrm{b}_{\mathrm{i} 1}+\lambda_{2} \times \mathrm{b}_{\mathrm{i} 2}+\ldots \ldots+\lambda_{\mathrm{k}} \times \mathrm{b}_{\mathrm{ik}}+\mathrm{e}_{\mathrm{i}}$

, where: $R_{i}=$ average return of the "i"th asset on the studied interval $b_{i 1 \ldots . . .} b_{i k}=$ sensitivity coefficients, previously estimated $\lambda_{1 \ldots} \ldots \lambda_{\mathrm{k}}=$ risk premiums associated with the 16 macroeconomic variables The regression has the sensitivity coefficients as independent variables and the average return of the stocks as the dependent variable; the non-zero risk premiums will correspond to macroeconomic variables that indeed have influence on the assets' return. Since steps 1 and 2 are already resolved, step 3 offers the values for the sensitivity coefficients presented in annex 2 . These coefficients will become independent variables in step 3 , in the regression who establishes which risk premiums will be non-zero. After resuming it, the regression gives statistical relevant risk premiums for 3 economic variables clearly and one extra marginally: BET-C, RON/USD, MIR şi IPI.

Summarizing, we obtain:

\begin{tabular}{|c|}
\hline Macroeconomic variables with influence \\
\hline BET-C, RON/USD, MIR, IPI \\
\hline
\end{tabular}

(B) The second possible approach has the following sequence of steps:

- Collecting data for each of the chosen variables related to the chosen interval of time.

- Identifying the number of factors with influence for the variables, using "principal component analysis" in SPSS; "scree plot" and "total variance explained" table are giving the proper number of factors to be used.

- Calculating "factor loadings" using a "varimax" rotation, because the variables are not correlated; otherwise an "oblimin" rotation is recommended; immediately follows a distribution of variables on each factor: a factor is sensible to a certain variable if its "factor loading" has a high absolute value.

- The determination of "factor scores" requires a combination of the time series for each variable with the relevant "factor loading" for each factor. $\mathrm{FSi}_{\mathrm{i}}=\sum_{i=1}^{n} \mathrm{Vit}_{\mathrm{i}} \times \mathrm{Fl}_{\mathrm{i}}$

- Previously-calculated "factor scores" will represent independent variables in a linear regression having as the dependent variable the returns of the stocks; the results of the regression estimate the sensitivity coefficients related to the influence factors: 
Available online at www.managementjournal.info

Table 1: Name, the listing category and the code of the stocks included in the sample

\begin{tabular}{|c|c|c|c|c|c|}
\hline Name & Categ. & Code & Name & Categ. & Code \\
\hline Alro S.A. & $\mathrm{I}$ & 1 & Compa S. A. & II & 31 \\
\hline Antibiotice S.A. & I & 2 & Compania energopetrol S.A. & II & 32 \\
\hline Azomureş S.A. & I & 3 & Electroargeş curtea DE Argeş & II & 33 \\
\hline Banca comercială carpatica S.A. & I & 4 & FARMACEUTICA REMEDIA DEVA & II & 34 \\
\hline Banca transilvania S.A. & I & 5 & Mechel targovişte S.A. & II & 35 \\
\hline Biofarm S.A. & I & 6 & Mefin S.A. & II & 36 \\
\hline Brd - groupe societe generale S.A. & I & 7 & Petrolexportimport S.A. & II & 37 \\
\hline concefa sibiu & I & 8 & Prodplast S.A. & II & 38 \\
\hline Impact developer \& contractor S.A. & I & 9 & Retrasib Sibiu & II & 39 \\
\hline Oil terminal S.A. & I & 10 & Şantierul naval orşova S.A. & II & 40 \\
\hline oltchim s.a. rm. vâlcea & I & 11 & SC Transilvania construcții SA & II & 41 \\
\hline OMV Petrom S.A. & I & 12 & Sinteza S.A. & II & 42 \\
\hline Prefab Bucureşti & I & 13 & Siretul paşcani S.A. & II & 43 \\
\hline Ropharma Braşov & I & 14 & T.M.K. - artrom S.A. & II & 44 \\
\hline S.S.I.F. Broker S.A. & I & 15 & Uamt S.A. & II & 45 \\
\hline SIF Banat Crişana S.A. & I & 16 & Uztel S.A. & II & 46 \\
\hline SIF Moldova S.A. & I & 17 & Ves Sa & II & 47 \\
\hline SIF Muntenia S.A. & I & 18 & Vrancart Sa & II & 48 \\
\hline SIF OLTENIA S.A. & I & 19 & Zentiva S.A. & II & 49 \\
\hline SIF Transilvania S.A. & I & 20 & Zimtub S.A. & II & 50 \\
\hline Socep S.A. & I & 21 & Ucm reşița S.A. & III & 51 \\
\hline Turbomecanica S.A. & I & 22 & Armătura S.A. & II & 52 \\
\hline Aerostar S.A. & II & 23 & comcm constanța & II & 53 \\
\hline Altur S.A. & II & 24 & dafora sa & II & 54 \\
\hline Amonil S.A. & II & 25 & Electroputere S.A. & II & 55 \\
\hline Bermas S.A. & II & 26 & romcarbon buzău & II & 56 \\
\hline Boromir Prod Buzău (Spicul) & II & 27 & Rompetrol rafinare S.A. & II & 57 \\
\hline Carbochim S.A. & II & 28 & Rompetrol well services S.A. & II & 58 \\
\hline Cemacon Zalău & II & 29 & Titan S.A. & II & 59 \\
\hline Comelf S.A. & II & 30 & Turism marea neagră S.A. & II & 60 \\
\hline
\end{tabular}

$\mathrm{R}_{\mathrm{i}}=\mathrm{a}_{\mathrm{i}}+\mathrm{Fs}_{1} \times \mathrm{b}_{\mathrm{i} 1}+\mathrm{Fs}_{2} \times \mathrm{b}_{\mathrm{i} 2}+\ldots \ldots .+\mathrm{Fs}_{\mathrm{k}} \times \mathrm{b}_{\mathrm{ik}}+\mathrm{e}_{\mathrm{i}}$

Where $R_{i}=$ average return of the "i"th asset on the studied interval, Fs $_{\text {s.... }}$ Fsk $_{\text {sk }}=$ previously-calculated "factor scores" $b_{i 1} \ldots . . b_{i k}=$ sensitivity coefficients

- Using these sensitivities as independent variables and the average return as dependent variable, we will see which factors are meaningful, and by doing so, which variables have truly an influence on assets' returns. As step 1 was already made by presenting the transformed values of the 16 variables in the above table, we can move to the next stages. "Scree plot" offers the following representation:

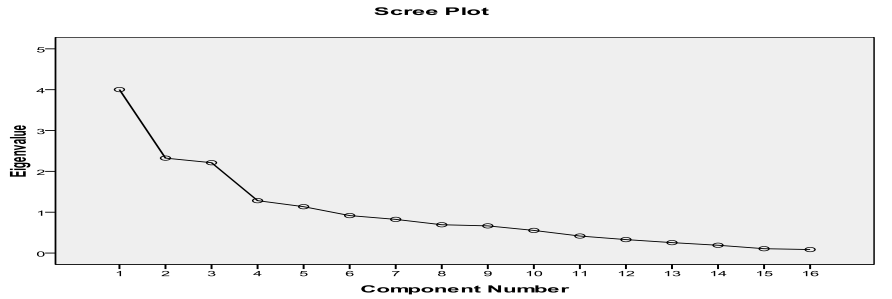

Since the graph trend tends to change its trajectory from vertically to horizontally somewhere between 5 and 6 factors, it is normal to choose one of the two cases. In the present situation 5 factors are chosen, explaining together more than $68 \%$ from the total variance, fact shown in annex 3 . The relevance of the choice is confirmed by KMO\&Bartlett test as well, offering a 0,673 level (the value can be only between 0 and 1 and it has as more meaning as the value is bigger; values over 0,5 can be considered relevant).Using the 5 factors in a "varimax" rotation, "factor loadings" values are obtained and presented in annex 4. A factor is influenced by a respective variable if the absolute value of the obtained "factor loading" is quite big. Although there is no strict rule of what a big value is, it can be considered that absolute values over $0,4-0,5$ are qualifying for that. Results' interpretations are below:

Fig. 1: Scree plot 


\begin{tabular}{cl}
\hline 1 & Relevant index for the national stock market: BET-C (points) \\
2 & Exchange rate national currency/important foreign currency: RON/USD (units) \\
3 & Exchange rate national currency/important foreign currency: RON/EUR (units) \\
4 & Change in the money supply: M1G (millions RON) \\
$\mathbf{5}$ & GDP indicator (millions RON) \\
$\mathbf{6}$ & Industrial production index: IPI (units) \\
$\mathbf{7}$ & Average interest on deposits in national currency: MIR (\% annually) \\
$\mathbf{9}$ & Relevant index of foreign stock market: FTSE (points) \\
10 & Relevant index of foreign stock market: SP 500 (points) \\
11 & Consumer price index: IPC (units) \\
12 & Change in oil price on the international market: OPG (units) \\
13 & Real consumption growth: RCG (units) \\
14 & Dnanticipated inflation: AIR (\% annually) \\
15 & Default risk premium: DP (\% annualy) \\
16 & Term structure of interest rates: TSIR (\% annually) \\
\hline
\end{tabular}

Table 3: Calculation method for different variables

\begin{tabular}{ll} 
Variable name & \\
\hline BET-C & First difference of the logarithmical value* \\
IPC & First difference of the logarithmical value \\
RON/USD & First difference of the logarithmical value \\
RON/EUR & First difference of the logarithmical value \\
M1G & First difference of the logarithmical value \\
GDP & First difference of the logarithmical value \\
IPI & First difference of the logarithmical value* \\
MIR & First difference of the logarithmical value \\
FTSE & First difference of the logarithmical value \\
SP 500 & First difference of the logarithmical value \\
OP & First difference of the logarithmical value* \\
RCG & Percentage change related to previous interval* \\
AIR & First difference of the logarithmical value* \\
DP & DP = interest for corporative bonds - interest for long term government bonds* \\
TSIR & TSIR = interest for long term government bonds - interest for short term treasury bills* \\
RIR & RIR = interest for short term treasury bills - consumer price index \\
\hline$*=$ variables are calculated in a similar or close way as in the Chen, Roll, Ross studyThe transformed values of the 16 chosen variables on the studied \\
interval (2005-2010) are presented in annex 1.
\end{tabular}

Factor 1: includes the national stock market index (positive correlation); 2 relevant ones on external stock markets (positive correlations); exchange rates between national currency and 2 important international currencies (negative correlations); and oil price on the international market (positive correlation);

Factor 2: is influenced by real consumption growth (positive correlation); by the consumer price index (positive correlation); and by unanticipated inflation (positive correlation);

Factor 3: includes real interest rate (negative correlation), default risk premium (positive correlation), average interest rate for deposits in national currency (negative correlation) and M1 money supply (positive correlation)

Factor 4: is composed by the gross domestic product (positive correlation) and by term structure of interest rates (positive correlation);

Factor 5: is composed by the industrial production index (positive correlation)

Stages 4 and 5 offer the "factor scores" values, presented in annexure 5, and for the sensitivity coefficients, presented in annexure 6.Last step of the methodology determines which of the 5 factors are significant and, implicitly, which of the macroeconomic variables truly influence the returns of the analyzed stocks. The result of the regression offers the below conclusions: 
Available online at www.managementjournal.info

Table 4:The following table shows the correlation between the transformed values of the variables

\begin{tabular}{|c|c|c|c|c|c|c|c|c|c|c|c|c|c|c|c|c|}
\hline & v1 & v2 & v3 & $\mathrm{v} 4$ & v5 & v6 & v7 & v8 & v9 & v10 & v11 & v12 & v13 & v14 & v15 & v16 \\
\hline v1 & 1,00 & & & & & & & & & & & & & & & \\
\hline v2 & $-0,54$ & 1,00 & & & & & & & & & & & & & & \\
\hline v3 & $-0,53$ & 0,61 & 1,00 & & & & & & & & & & & & & \\
\hline $\mathrm{v} 4$ & 0,77 & $-0,39$ & $-0,55$ & 1,00 & & & & & & & & & & & & \\
\hline v5 & 0,71 & $-0,43$ & $-0,47$ & 0,87 & 1,00 & & & & & & & & & & & \\
\hline v6 & 0,03 & $-0,18$ & $-0,07$ & $-0,03$ & 0,05 & 1,00 & & & & & & & & & & \\
\hline v7 & $-0,02$ & $-0,08$ & $-0,06$ & $-0,05$ & $-0,13$ & 0,16 & 1,00 & & & & & & & & & \\
\hline v8 & $-0,17$ & 0,13 & 0,03 & $-0,16$ & $-0,15$ & 0,00 & 0,10 & 1,00 & & & & & & & & \\
\hline v9 & 0,00 & 0,07 & $-0,04$ & 0,09 & 0,01 & 0,09 & $-0,09$ & 0,04 & 1,00 & & & & & & & \\
\hline $\mathrm{v} 10$ & 0,38 & $-0,21$ & $-0,37$ & 0,40 & 0,37 & $-0,09$ & $-0,08$ & $-0,03$ & $-0,10$ & 1,00 & & & & & & \\
\hline v11 & 0,20 & $-0,30$ & $-0,21$ & 0,18 & 0,15 & 0,37 & 0,13 & $-0,25$ & 0,06 & 0,08 & 1,00 & & & & & \\
\hline v12 & 0,06 & $-0,17$ & $-0,27$ & $-0,01$ & $-0,03$ & 0,21 & 0,13 & $-0,01$ & 0,01 & 0,01 & 0,27 & 1,00 & & & & \\
\hline v13 & $-0,11$ & 0,21 & 0,18 & $-0,10$ & $-0,09$ & $-0,36$ & $-0,10$ & 0,27 & 0,04 & $-0,08$ & $-0,87$ & $-0,29$ & 1,00 & & & \\
\hline v14 & $-0,13$ & 0,18 & $-0,05$ & $-0,02$ & $-0,06$ & $-0,07$ & 0,21 & $-0,09$ & $-0,04$ & 0,10 & $-0,12$ & $-0,10$ & 0,09 & 1,00 & & \\
\hline v15 & $-0,19$ & 0,27 & 0,08 & $-0,17$ & $-0,21$ & $-0,21$ & 0,01 & $-0,11$ & 0,21 & 0,05 & $-0,07$ & $-0,17$ & 0,07 & 0,45 & 1,00 & \\
\hline v16 & $-0,13$ & 0,25 & 0,07 & $-0,09$ & $-0,14$ & $-0,17$ & 0,13 & $-0,13$ & 0,07 & 0,07 & 0,07 & $-0,17$ & $-0,11$ & 0,68 & 0,64 & 1,00 \\
\hline
\end{tabular}

\begin{tabular}{|l|l|l|l|l|}
\hline F1 & F2 & F3 & F4 & F5 \\
\hline significant & $\begin{array}{l}\text { non- } \\
\text { significant }\end{array}$ & $\begin{array}{l}\text { non- } \\
\text { significant }^{-}\end{array}$ & $\begin{array}{l}\text { non- } \\
\text { significant }\end{array}$ & significant \\
\hline
\end{tabular}

As we know from a previous stage the compound of factors, the conclusion is that only variables forming factors 1 and 5 have influence on assets' return, being: industrial production index, national stock market index, relevant ones on external stock markets, exchange rates between national currency and the 2 important international currencies, and oil price on the international market. Summarizing, we obtain:

\begin{tabular}{|l|}
\hline Macroeconomic variables with influence \\
\hline IPI, BET-C, FTSE, S\&P500, RON/EUR, RON/USD, OP \\
\hline
\end{tabular}

\section{Conclusions and Limitations}

Without the request that the current article describes totally and absolutely correct the set of macroeconomic variables which might influence stock market stocks' returns, there were some obtained results, resumed here. Comparing the conclusions of both used approaches, following variables were found as significant:

\begin{tabular}{|l|l|l|}
\hline & Method A & Method B \\
\hline $\begin{array}{l}\text { 2005-2010 } \\
\text { interval }\end{array}$ & $\begin{array}{l}\text { BET-C, } \\
\text { RON/USD, } \\
\text { MIR, IPI }\end{array}$ & IPI, BET-C, FTSE, S\&P500, \\
\hline
\end{tabular}

It can be observed that the first approach offered 4 economical variables having influence, whereas the second one offered more, as much as 7 . Only 2 variables are common to both approaches, and those are the national stock market index and the exchange rate between the national currency and the American dollar. Among the variables found as significant by the famous studies, only the industrial production index is relevant for the Romanian market. The unanticipated inflation, the term structure of interest rates and the default premium risk changes, found as significant by Chen, Roll, Ross and other analyzes, seem to have little to no effect on the stocks listed on Bucharest Stock Exchange. But variables like stock market indexes (national and foreign), the exchange rate between the national and international currencies, oil price on the international market or the interest rates for deposits in national currency seem to be significant in this context, even if their relevance is obtained only through 1 of the 2 used approaches. The results of this testing and their interpretations can not be necessarily considered as references. The following aspects used in this empirical process could possibly provoke some errors and, through this, some deviations from a set of accurate conclusions.

- The availability and the accuracy of the data is not fully guaranteed, and the missing observations were completed by interpolation, which is not similar with being totally exact.

- Using a "proxy" for the riskless interest rate.

- The existence of some possible miscalculating, including some caused by the author.

\section{Acknowledgements}

This paper was co-financed by European Social Fond, through POSDRU 2007-2013, project nr.88/1.5/S/55287, DOESEC. 


\section{Available online at www.managementjournal.info}

\section{References}

1. Ross S(1976) The arbitrage theory of capital asset pricing.", Journal of Economic Theory, 343-62.

2. Copeland T, Weston F (2004) Financial Theory and Corporate Policy $4^{\text {th }}$ edition, Addison-Wesley Publishing Company.

3. Mishkin F(2009) The economics of money, banking and financial markets $9^{\text {th }}$ edition, Pearson.

4. Chen NF, Roll R, Ross S (1986) Economic forces and the stock market. The J. Business 3:59;383-403;

5. Virtanen IN, Ylli-Olli P(1989) Arbitrage pricing theory and its empirical applicability for the Helsinki stock exchange. Working Paper 7, European Institute for Advanced Studies in Management.

6. Wahlroos B. Berglund P(1986) Stock returns, inflationary expectations and real activity. J. Banking and Finance 10: 377-89.

7. Asprem M (1989) Stock prices, asset portfolios and macroeconomic variables in ten European countries. J. Banking and Finance 13:589-612.

8. Viskari J(1992) News and stock prices: some further results. The Finnish Journal of Business Economics 4:371-76.

9. Loflund A(1992) Arbitrage pricing theory in a small open economy -empirical evidence from the Swedish stock market. Research reports 26, Swedish School of Economics and Business Administration.

10.Clare AD, Thomas SH (1994) Macroeconomic factors: the APT and the UK stock market. J. Business Finance and Accounting 3:21.

11.Beenstock M, Chan K (1988) Economic forces in the London stock market. Oxford Bulletin of Economics and Statistics 50.

12. Groenewold N, Fraser $\mathrm{P}(1997)$ Share prices and macroeconomic factors. J. Business Finance and Accounting 24(9)1367-83.

13.Cagnetti A (2007) CAPM and APT in the Italian stock market: an empirical study. Unpublished article.

14.Iqbal J, Haider A (2005) APT: evidence from an emerging stock market. The Lahore J. Economics 12339.

15.Bîlbîie F, Gherman A, Tureatcă M (1998) Teoria generala a arbitrajului si modelul de evaluare APT. Articole fundamentale în teoria financiară, 298-322. 
Available online at www.managementjournal.info

Annexure1: The time series of the unanticipated components of the 16 economic variables tested

\begin{tabular}{|c|c|c|c|c|c|c|c|c|c|c|c|c|c|c|c|c|}
\hline & BET-C & RON/EUR & RON/USD & S\&P500 & FTSE & M1 & PIB & GDP & IPI & $\mathrm{OP}$ & $\mathrm{DP}$ & TSIR & RIR & IPC & AIR & $\mathrm{RPG}$ \\
\hline $\begin{array}{l}\text { jan. } \\
05\end{array}$ & 0,0675 & $-0,0073$ & $-0,025$ & 0,0121 & 0,0226 & 0,0168 & 0 & $\begin{array}{l} \\
0,1032\end{array}$ & $\begin{array}{l} \\
0,1371\end{array}$ & 0,0917 & 7,25 & 0 & $-8,9$ & $\begin{array}{l} \\
0,0134\end{array}$ & $\begin{array}{l} \\
0,1891\end{array}$ & 0,8 \\
\hline $\begin{array}{l}\text { feb. } \\
05\end{array}$ & 0,0792 & $-0,0377$ & $-0,029$ & 0,0188 & 0,0237 & 0,0297 & 0 & 0,1385 & 0,0863 & 0,1507 & 7,25 & 1,8 & $-3,7$ & 0 & $-0,139$ & 0,6 \\
\hline $\begin{array}{l}\text { mar. } \\
05\end{array}$ & $-0,185$ & $-0,0117$ & $-0,0242$ & $-0,0193$ & $\begin{array}{l}\bar{l} \\
0,0151\end{array}$ & 0,0329 & 0 & 0,0812 & $\begin{array}{l}\overline{-} \\
0,0246\end{array}$ & $\begin{array}{l}-\overline{-} \\
0,0301\end{array}$ & 0,45 & 0 & -10 & $\overline{-}-0018$ & $\begin{array}{l}-1598 \\
0,15\end{array}$ & 0,3 \\
\hline $\begin{array}{l}\text { apr. } \\
05\end{array}$ & $-0,0673$ & $-0,0013$ & 0,017 & $-0,0203$ & $\begin{array}{l}- \\
0,0191\end{array}$ & 0,0479 & 0,0141 & 0,2165 & 0,0041 & 0,0752 & 7,25 & -5 & -5 & 0,0119 & 0,4221 & 1,8 \\
\hline $\begin{array}{l}\text { may. } \\
05\end{array}$ & $-0,0125$ & $-0,003$ & 0,0165 & 0,0295 & 0,0333 & 0,0735 & 0 & $-0,095$ & 0,126 & 0,1463 & 7,25 & 2,1 & $-4,7$ & 0 & $\begin{array}{l}- \\
0,1233\end{array}$ & 0,3 \\
\hline $\begin{array}{l}\text { jun. } \\
05\end{array}$ & 0,0307 & $-0,0012$ & 0,0408 & $-0,0002$ & 0,0296 & 0,0851 & 0 & $\begin{array}{l}-0687 \\
0,\end{array}$ & $\begin{array}{l}- \\
0,0743\end{array}$ & 0,0457 & 0,15 & 0 & $-9,3$ & $\begin{array}{l}-0028 \\
0,028\end{array}$ & $-0,139$ & 0,3 \\
\hline $\begin{array}{l}\text { jul. } \\
05\end{array}$ & 0,0909 & $-0,0135$ & $-0,0029$ & 0,0354 & 0,0325 & 0,0274 & - 0,0009 & 0,0086 & 0,1009 & 0,1079 & 7,25 & 0 & $-8,9$ & 0,0036 & 0 & 1 \\
\hline $\begin{array}{l}\text { aug. } \\
05\end{array}$ & 0,0113 & $-0,0169$ & $-0,0378$ & $-0,0113$ & 0,0028 & - & 0 & 0,0294 & $\begin{array}{l}-0194 \\
0,0194\end{array}$ & 0,0085 & 7,25 & 5,4 & $-8,5$ & 0,0037 & $\begin{array}{l}-1598 \\
0,1\end{array}$ & 0,1 \\
\hline $\begin{array}{l}\text { sep. } \\
05\end{array}$ & 0,0953 & 0,0013 & 0,0048 & 0,0069 & 0,0335 & 0,0603 & 0 & 0,0922 & 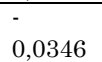 & 0,0606 & 1,85 & 0 & $-8,1$ & 0,0036 & 0 & 0,6 \\
\hline $\begin{array}{l}\text { oct. } \\
05\end{array}$ & $-0,0163$ & 0,0248 & 0,0437 & $-0,0179$ & 0,0297 & 0,0006 & 0,0153 & 0,1746 & 0,0061 & $\begin{array}{l}- \\
0,0742\end{array}$ & 7,25 & 0 & $-8,7$ & 0,0037 & 0,1598 & 0,9 \\
\hline $\begin{array}{l}\text { nov. } \\
05\end{array}$ & 0,0814 & 0,015 & 0,0344 & 0,0346 & 0,0197 & $\begin{array}{l}- \\
0,0174\end{array}$ & 0 & 0,0839 & 0,058 & 0,0219 & 7,25 & 0 & $-8,6$ & 0,0055 & 0 & 1,2 \\
\hline $\begin{array}{l}\text { dec. } \\
05\end{array}$ & $-0,0294$ & 0,0017 & $-0,0045$ & $-0,001$ & 0,0355 & 0,1053 & 0 & 0,0559 & 0,0364 & 0,1084 & 7,25 & 0 & 8,89 & 0,0009 & 0 & 0,5 \\
\hline $\begin{array}{l}\text { jan. } \\
06\end{array}$ & 0,1912 & $-0,004$ & $-0,0254$ & 0,0252 & 0,0248 & 0,0035 & 0,0018 & 0,0024 & $-0,009$ & 0,0647 & 7,25 & 0 & 8,49 & 0,0026 & 0,3733 & 1,03 \\
\hline $\begin{array}{l}\text { feb. } \\
06\end{array}$ & 0,0149 & $-0,029$ & $-0,0144$ & 0,0004 & 0,0054 & - & 0 & - & $\begin{array}{l}- \\
0,1184\end{array}$ & 0,014 & 7,25 & 0 & 8,41 & - & $\begin{array}{l}- \\
0,5331\end{array}$ & 0,24 \\
\hline $\begin{array}{l}\text { mar. } \\
06\end{array}$ & $-0,0754$ & $-0,0093$ & $-0,0155$ & 0,0111 & 0,0295 & 0,0044 & 0 & 0,1235 & $\begin{array}{l}- \\
0,0181\end{array}$ & 0,1203 & 7,25 & 0 & 6,92 & 0,0008 & $\begin{array}{l}- \\
0,1879\end{array}$ & 0,21 \\
\hline $\begin{array}{l}\text { apr. } \\
06\end{array}$ & 0,0256 & $-0,0047$ & $-0,024$ & 0,012 & 0,0098 & 0,0434 & $\begin{array}{l}- \\
0,0063\end{array}$ & 0,0022 & 0,0534 & 0,007 & 7,25 & 0 & 7,26 & 0,0138 & 0 & 0,42 \\
\hline $\begin{array}{l}\text { may. } \\
06\end{array}$ & $-0,0618$ & 0,0046 & $-0,0371$ & $-0,0314$ & $-0,051$ & 0,0553 & 0 & 0,0463 & 0,1098 & 0,0014 & 7,25 & 0 & $\begin{array}{l}- \\
7,11\end{array}$ & 0,0032 & 0 & 0,6 \\
\hline $\begin{array}{l}\text { jun. } \\
06\end{array}$ & $-0,0209$ & 0,0117 & 0,0204 & 0,0001 & 0,019 & 0,0553 & 0 & 0,0208 & - & 0,0531 & 7,25 & 0 & 6,21 & 0,0014 & $\begin{array}{l}-2285 \\
0,2\end{array}$ & 0,15 \\
\hline $\begin{array}{l}\text { jul. } \\
06\end{array}$ & 0,0741 & 0,0067 & 0,0055 & 0,0051 & 0,0161 & 0,0309 & $\overline{-}-0092$ & 0,0063 & 0,1437 & - 0,0206 & 7,25 & 0 & $\begin{array}{l}- \\
6,02 \\
\end{array}$ & 0,0085 & 0 & 0,11 \\
\hline $\begin{array}{l}\text { aug. } \\
06\end{array}$ & 0,0034 & $-0,0126$ & $-0,0228$ & 0,0211 & 0,0038 & 0,0359 & 0 & 0,0435 & $-0,027$ & 0,1528 & 7,25 & 0 & 5,48 & 0,0018 & 0,2935 & 0,07 \\
\hline $\begin{array}{l}\text { sep. } \\
06\end{array}$ & 0,0461 & $-0,0002$ & 0,0058 & 0,0242 & 0,0093 & 0,0092 & 0 & 0,0082 & 0,0243 & $\begin{array}{l}- \\
0,0891\end{array}$ & 7,25 & 0 & $-4,8$ & 0,0051 & 0 & 0,05 \\
\hline $\begin{array}{l}\text { oct. } \\
06\end{array}$ & 0,0818 & $-0,0022$ & 0,0073 & 0,031 & 0,0278 & 0,0366 & 0,0326 & 0,0479 & $\begin{array}{l}- \\
0,0262\end{array}$ & 0 & 7,25 & 0 & 4,67 & 0,0064 & 0 & 0,21 \\
\hline $\begin{array}{l}\text { nov. } \\
06\end{array}$ & $-0,0347$ & $-0,0068$ & $-0,0276$ & 0,0164 & 0,0132 & 0,0197 & 0 & 0,0096 & 0,0415 & 0,0587 & 7,25 & 0 & 4,87 & 0,0013 & 0,2935 & 1,09 \\
\hline $\begin{array}{l}\text { dec. } \\
06\end{array}$ & 0,0064 & $-0,0235$ & $-0,0492$ & 0,0125 & 0,0281 & 0,1281 & 0 & 0,0214 & 0,061 & $-0,15$ & 7,25 & 6,61 & 4,01 & 0,0019 & 0 & 0,74 \\
\hline $\begin{array}{l}\text { jan. } \\
07\end{array}$ & 0,0825 & $-0,006$ & 0,0115 & 0,014 & $\begin{array}{l}- \\
0,0029\end{array}$ & 0,058 & 0,0053 & 0,3192 & $\begin{array}{l} \\
0,0217\end{array}$ & 0,0988 & 0,64 & 0,6 & 2,2 & - & $\begin{array}{l}- \\
0,7045\end{array}$ & 0,2 \\
\hline $\begin{array}{l}\text { feb. } \\
07\end{array}$ & 0,0291 & $-0,0033$ & $-0,0097$ & $-0,0221$ & 0,0051 & 0,0124 & 0 & 0,0072 & 0,1371 & 0,0246 & 0,64 & 0,98 & 2,39 & 0,0019 & 0,6981 & 0,04 \\
\hline $\begin{array}{l}\text { mar. } \\
07\end{array}$ & $-0,0104$ & $-0,0039$ & $-0,0169$ & 0,0099 & 0,0219 & 0,0462 & 0 & 0 & 0,0152 & 0,0633 & 0,22 & 0,18 & 3,26 & 0,0015 & 0 & 0,07 \\
\hline $\begin{array}{l}\text { apr. } \\
07\end{array}$ & 0,0666 & $-0,0103$ & $-0,0303$ & 0,0424 & 0,0221 & 0,0087 & 0,0018 & $\begin{array}{l}- \\
0,0204\end{array}$ & 0,068 & $\begin{array}{l}- \\
0,0117\end{array}$ & 0,04 & $-0,04$ & 3,42 & 0,0011 & 0,6981 & 0,52 \\
\hline $\begin{array}{l}\text { may. } \\
07\end{array}$ & $-0,0061$ & $-0,015$ & $-0,0152$ & 0,032 & 0,0264 & 0,0265 & 0 & 0,0074 & 0,0664 & 0,0667 & 0,19 & $-0,16$ & 3,38 & 0,0004 & 0,411 & 0,64 \\
\hline $\begin{array}{l}\text { jun. } \\
07\end{array}$ & 0,1048 & $-0,018$ & $-0,0109$ & $-0,0179$ & 0,0021 & 0,0518 & 0 & 0,0119 & $\overline{-}, 0347$ & 0,1072 & $\overline{0}, 02$ & $-0,13$ & 3,15 & - & 0 & 0,14 \\
\hline $\begin{array}{l}\text { jul. } \\
07\end{array}$ & 0,0675 & $-0,0292$ & $-0,0514$ & $-0,0326$ & 0,0382 & 0,0592 & 0,0079 & $-0,006$ & 0,0464 & 0,0265 & 0,01 & $-0,02$ & 1,92 & 0,0018 & 0 & 0,29 \\
\hline $\begin{array}{l}\text { aug. } \\
07\end{array}$ & 0 & 0,0283 & 0,0355 & 0,0128 & $-0,009$ & 0,0273 & 0 & 0,0045 & $-0,015$ & 0,0993 & 0,14 & $-0,01$ & 0,68 & 0,0093 & 0 & 0,86 \\
\hline $\begin{array}{l}\text { sep. } \\
07\end{array}$ & $-0,0605$ & 0,0374 & 0,0176 & 0,0352 & 0,0256 & 0,0234 & 0 & 0 & $\begin{array}{l}\overline{-} \\
0,0139\end{array}$ & 0,0893 & 0,3 & 0,27 & 0,16 & 0,0101 & 0,2935 & 1,08 \\
\hline $\begin{array}{l}\text { oct. } \\
07\end{array}$ & 0,0457 & 0,0018 & $-0,022$ & 0,0147 & 0,0387 & 0,022 & - & 0,003 & 0,0928 & 0,1139 & 0,27 & $-0,58$ & 1,18 & 0,0076 & 0,2285 & 0,97 \\
\hline $\begin{array}{l}\text { nov. } \\
07\end{array}$ & $-0,0965$ & 0,0347 & 0,0036 & $-0,045$ & $-0,044$ & 0,0663 & 0 & 0,018 & 0,0955 & 0,0406 & 0,27 & $-0,38$ & 1,28 & 0,0016 & 0 & 0,93 \\
\hline $\begin{array}{l}\text { dec. } \\
07\end{array}$ & 0,0598 & 0,0166 & 0,0248 & $-0,0087$ & 0,0038 & 0,0791 & 0 & 0,0074 & 0,0047 & 0,0147 & 0,47 & 0,35 & 1,68 & 0,0009 & 0 & 0,64 \\
\hline $\begin{array}{l}\text { jan. } \\
08\end{array}$ & $-0,2546$ & 0,0454 & 0,0352 & $-0,0631$ & $\begin{array}{l}- \\
0,0936\end{array}$ & 0,0043 & 0,0234 & 0,0058 & $-0,116$ & 0,0227 & $\begin{array}{l}- \\
2,29\end{array}$ & 0,35 & 0,97 & 0,0065 & 0,61 & 0,86 \\
\hline $\begin{array}{l}\text { feb. } \\
08\end{array}$ & 0,0068 & $-0,0109$ & $-0,014$ & $-0,0354$ & 0,0007 & 0,031 & 0 & 0,0317 & 0,2133 & 0,1116 & 2,29 & 0,04 & 0,8 & 0,0066 & 0,1233 & 0,7 \\
\hline $\begin{array}{l}\text { mar. } \\
08\end{array}$ & $-0,0467$ & 0,0187 & $-0,0327$ & $-0,006$ & 0,0314 & 0,0119 & 0 & 0,0403 & 0,0516 & 0,074 & $\begin{array}{l}- \\
2,47\end{array}$ & 0,2 & 0,81 & 0,006 & $-0,139$ & 0,67 \\
\hline $\begin{array}{l}\text { apr. } \\
08 \\
\end{array}$ & 0,0126 & $-0,0215$ & $-0,0369$ & 0,0465 & 0,0654 & 0,0138 & 0,0129 & 0,0608 & 0,0062 & 0,1182 & $\begin{array}{l}- \\
2,63\end{array}$ & $-0,61$ & 1,76 & 0 & 0 & 0,52 \\
\hline
\end{tabular}


Available online at www.managementjournal.info

\begin{tabular}{|c|c|c|c|c|c|c|c|c|c|c|c|c|c|c|c|c|}
\hline $\begin{array}{l}\text { may. } \\
08\end{array}$ & 0,0876 & 0,0046 & 0,0178 & 0,0106 & $\begin{array}{l} \\
0,0056 \\
\end{array}$ & 0,0245 & 0 & 0,05 & 0,0071 & 0,0733 & $\begin{array}{l}- \\
2,61 \\
\end{array}$ & $-0,89$ & 2,02 & $\begin{array}{l}- \\
0,0015 \\
\end{array}$ & $\begin{array}{l}- \\
0,1598 \\
\end{array}$ & 0,49 \\
\hline $\begin{array}{l}\text { jun. } \\
08 \\
\end{array}$ & $-0,1685$ & $-0,001$ & $-0,0004$ & $-0,0899$ & 0,0733 & 0,0575 & 0 & 0,0672 & 0,0088 & 0,0013 & 2,74 & $-0,72$ & 1,7 & 0,0014 & 0 & 0,28 \\
\hline $\begin{array}{l}\text { jul. } \\
08 \\
\end{array}$ & $-0,0559$ & $-0,0212$ & $-0,0355$ & $-0,0099$ & $\begin{array}{l}- \\
0,0387\end{array}$ & $\begin{array}{l}- \\
0,0085\end{array}$ & 0,0095 & 0,037 & 0,0008 & $\begin{array}{l} \\
0,1512\end{array}$ & $\begin{array}{l}- \\
3,02 \\
\end{array}$ & $-0,46$ & 2,92 & 0,0039 & 0 & 0,69 \\
\hline $\begin{array}{l}\text { aug. } \\
08\end{array}$ & $-0,0782$ & $-0,0147$ & 0,0382 & 0,0121 & 0,0406 & 0,009 & 0 & 0,0482 & 0,0113 & $\overline{0}, 1207$ & $\begin{array}{l}- \\
3,48 \\
\end{array}$ & $-1,23$ & 3,86 & 0,0094 & $\begin{array}{l}- \\
0,1879\end{array}$ & $\overline{-}, 09$ \\
\hline $\begin{array}{l}\text { sep. } \\
08 \\
\end{array}$ & $-0,2258$ & 0,0276 & 0,0683 & $-0,0952$ & $\begin{array}{l} \\
0,1395\end{array}$ & 0,0173 & 0 & 0,0249 & 0,0018 & $\begin{array}{l}- \\
0,3389\end{array}$ & $\begin{array}{l}- \\
2,93 \\
\end{array}$ & $-0,1$ & 3,91 & $\begin{array}{l}-0067 \\
0,006\end{array}$ & 0 & 0,4 \\
\hline $\begin{array}{l}\text { oct. } \\
08\end{array}$ & $-0,3997$ & 0,0325 & 0,1086 & $-0,1856$ & 0,1133 & $\begin{array}{l}- \\
0,0093\end{array}$ & $\begin{array}{l}- \\
0,0122\end{array}$ & 0,0478 & 0,006 & $\begin{array}{l}- \\
0,3291\end{array}$ & $-4,2$ & $-0,35$ & 6,26 & 0,0009 & 0,1879 & 1,06 \\
\hline $\begin{array}{l}\text { nov. } \\
08\end{array}$ & 0,0036 & 0,008 & 0,052 & $-0,0778$ & - & 0,0075 & 0 & 0,0786 & 0,0136 & $-0,403$ & 5,65 & $-0,98$ & 7,68 & 0,0061 & 0,1879 & 0,32 \\
\hline $\begin{array}{l}\text { dec. } \\
08 \\
\end{array}$ & $-0,0965$ & 0,0364 & $-0,0207$ & 0,0078 & 0,0335 & 0,0022 & 0 & 0,0871 & 0,0092 & 0,0039 & -6 & $-1,24$ & 7,52 & $\begin{array}{l}- \\
0,0041\end{array}$ & 0 & 0,23 \\
\hline $\begin{array}{l}\text { jan. } \\
09 \\
\end{array}$ & $-0,2691$ & 0,0779 & 0,0975 & $-0,0896$ & 0,0663 & $\begin{array}{l}- \\
0,0519\end{array}$ & 0,0355 & 0,0906 & 0,0158 & 0,0633 & 5,99 & $-1,37$ & 5,96 & 0,0038 & 0,9145 & 1,24 \\
\hline $\begin{array}{l}\text { feb. } \\
09\end{array}$ & $-0,1937$ & 0,0121 & 0,0453 & $-0,1164$ & $\begin{array}{l}- \\
0,0802\end{array}$ & $\begin{array}{l}- \\
0,0357\end{array}$ & 0 & 0,0355 & $-0,005$ & 0,2506 & $\begin{array}{l}- \\
4,48\end{array}$ & $-0,02$ & 4,76 & 0,0017 & $\begin{array}{l}- \\
0,0926\end{array}$ & 0,88 \\
\hline $\begin{array}{l}\text { mar. } \\
09\end{array}$ & 0,2199 & $-0,0005$ & $-0,019$ & 0,0819 & 0,0248 & $\begin{array}{l}- \\
0,0407\end{array}$ & 0 & 0,0238 & $\begin{array}{l}- \\
0,0268\end{array}$ & 0,0565 & 4,45 & 0,02 & 5,03 & 0,0017 & $\begin{array}{l}- \\
0,2119\end{array}$ & 0,5 \\
\hline $\begin{array}{l}\text { apr. } \\
09 \\
\end{array}$ & 0,2287 & $-0,0204$ & $-0,0332$ & 0,0898 & 0,0778 & $\begin{array}{l}- \\
0,0121\end{array}$ & $\begin{array}{l}- \\
0,0378 \\
\end{array}$ & $-0,005$ & $\begin{array}{l}- \\
0,0172 \\
\end{array}$ & 0,1898 & $-4,5$ & $-0,34$ & 5,54 & $\begin{array}{l}- \\
0,0024\end{array}$ & $\begin{array}{l}- \\
0,2623 \\
\end{array}$ & 0,27 \\
\hline $\begin{array}{l}\text { may. } \\
09\end{array}$ & 0,0554 & $-0,0063$ & $-0,0393$ & 0,0517 & 0,0402 & 0,0077 & 0 & 0,0253 & 0,0432 & 0,1862 & 4,15 & $-0,1$ & 5,39 & 0,0047 & 0,1598 & 0,01 \\
\hline $\begin{array}{l}\text { jun. } \\
09 \\
\end{array}$ & 0,0213 & 0,0104 & $-0,0171$ & 0,0002 & $\begin{array}{l}- \\
0,0389\end{array}$ & 0,0229 & 0 & $-0,058$ & 0,005 & $\begin{array}{l}- \\
0,0902\end{array}$ & $\begin{array}{l}- \\
4,15 \\
\end{array}$ & 0,04 & 5,86 & $\begin{array}{l}- \\
0,0009\end{array}$ & $\begin{array}{l}- \\
0,1879\end{array}$ & 0,2 \\
\hline $\begin{array}{l}\text { jul. } \\
09\end{array}$ & 0,0967 & 0,001 & $-0,0032$ & 0,0716 & 0,0811 & $-0,003$ & $\begin{array}{l}- \\
0,0649 \\
\end{array}$ & $\begin{array}{l}- \\
0,0825 \\
\end{array}$ & 0,0041 & 0,1118 & $\begin{array}{l}- \\
3,96 \\
\end{array}$ & $-0,51$ & 5,8 & $\begin{array}{l}- \\
0,0076 \\
\end{array}$ & $\begin{array}{l}- \\
0,2285 \\
\end{array}$ & $\begin{array}{l}- \\
0,07 \\
\end{array}$ \\
\hline $\begin{array}{l}\text { aug. } \\
09\end{array}$ & 0,083 & 0,0004 & $-0,0122$ & 0,033 & 0,0632 & 0,0163 & 0 & 0,0908 & 0,0179 & $\begin{array}{l}- \\
0,0295\end{array}$ & $\begin{array}{l}- \\
3,25 \\
\end{array}$ & $-0,47$ & 5,51 & 0,0009 & 0 & $\begin{array}{l}- \\
0,19 \\
\end{array}$ \\
\hline $\begin{array}{l}\text { sep. } \\
09 \\
\end{array}$ & 0,0536 & 0,0048 & $-0,0159$ & 0,0351 & 0,0448 & $\begin{array}{l}- \\
0,0272\end{array}$ & 0 & 0,0598 & 0,0097 & 0,1006 & $\begin{array}{l}- \\
2,98\end{array}$ & 0,04 & 5,65 & 0,0002 & 0 & 0,39 \\
\hline $\begin{array}{l}\text { oct. } \\
09 \\
\end{array}$ & $-0,0017$ & 0,0108 & $-0,0071$ & $-0,02$ & - 0,0175 & $\begin{array}{l}- \\
0,0299\end{array}$ & 0,0267 & 0,0349 & 0 & 0,0292 & $\begin{array}{l}- \\
2,99\end{array}$ & 0,02 & 5,33 & 0,0061 & 0 & 0,44 \\
\hline $\begin{array}{l}\text { nov. } \\
09\end{array}$ & 0,0472 & 0,0007 & $-0,0057$ & 0,0558 & 0,0285 & 0,0055 & 0 & 0,0164 & 0,0113 & 0,0457 & -3 & 0 & 5,26 & 0,0033 & 0 & 0,67 \\
\hline $\begin{array}{l}\text { dec. } \\
09 \\
\end{array}$ & $-0,0242$ & $-0,0148$ & 0,0074 & 0,0176 & 0,0419 & 0,0093 & 0 & 0,0135 & 0,0064 & 0,2153 & -3 & $-1,2$ & 4,8 & 0,0009 & 0 & 0,32 \\
\hline $\begin{array}{l}\text { jan. } \\
10 \\
\end{array}$ & 0,0887 & $-0,0201$ & 0,0015 & $-0,0377$ & $\begin{array}{l}- \\
0,0423 \\
\end{array}$ & $\begin{array}{l}- \\
0,0353 \\
\end{array}$ & $-0,002$ & $-0,019$ & 0,0167 & 0,2671 & $-1,8$ & $-1,35$ & 4,27 & 0,0044 & 1,5192 & 1,68 \\
\hline $\begin{array}{l}\text { feb. } \\
10\end{array}$ & 0,0322 & $-0,0056$ & 0,0364 & 0,0281 & 0,0315 & 0,0026 & 0 & $\begin{array}{l}- \\
0,0468\end{array}$ & $\begin{array}{l} \\
0,0024\end{array}$ & $\begin{array}{l}- \\
0,0263\end{array}$ & $\begin{array}{l}- \\
0,41\end{array}$ & $-0,59$ & 3,21 & 0,0068 & $\begin{array}{l}- \\
0,6807\end{array}$ & 0,2 \\
\hline $\begin{array}{l}\text { mar. } \\
10\end{array}$ & 0,1388 & $-0,0073$ & 0,0014 & 0,0572 & 0,0589 & $\begin{array}{l}- \\
0,0047\end{array}$ & 0 & $\begin{array}{l}- \\
0,0539\end{array}$ & 0,0326 & 0,069 & 0,18 & 0,34 & 2,29 & 0,0028 & $\begin{array}{l}- \\
0,2623\end{array}$ & 0,22 \\
\hline $\begin{array}{l}\text { apr. } \\
10\end{array}$ & $-0,0245$ & 0,0099 & 0,0212 & 0,0146 & 0,0225 & 0,0012 & 0,0146 & 0,0746 & 0,0015 & 0,0457 & 0,09 & 0,98 & 1,6 & 0,0008 & 0,1598 & 0,35 \\
\hline $\begin{array}{l}\text { may. } \\
10\end{array}$ & $-0,1514$ & 0,011 & 0,0766 & $-0,0855$ & $\begin{array}{l}- \\
0,0679\end{array}$ & 0,0297 & 0 & $\begin{array}{l}- \\
0,0521\end{array}$ & $\begin{array}{l}- \\
0,0123\end{array}$ & $\begin{array}{l}- \\
0,1414\end{array}$ & 0 & 0,66 & 1,93 & 0,0013 & $\begin{array}{l}- \\
0,1879\end{array}$ & 0,15 \\
\hline $\begin{array}{l}\text { jun. } \\
10 \\
\end{array}$ & $-0,0513$ & 0,0156 & 0,044 & $-0,0554$ & $\begin{array}{l}- \\
0,0538\end{array}$ & 0,0229 & 0 & 0,0312 & 0,0046 & 0,0131 & 0,03 & 0,31 & 0,35 & 0,0004 & 0 & 0,16 \\
\hline $\begin{array}{l}\text { jul. } \\
10\end{array}$ & 0,0556 & 0,005 & $-0,0386$ & 0,0665 & 0,0671 & $\begin{array}{l}- \\
0,0081\end{array}$ & 0,0387 & $\begin{array}{l}- \\
0,0139\end{array}$ & 0,0054 & 0,0117 & $-0,1$ & 0,11 & $\begin{array}{l}- \\
0,59 \\
\end{array}$ & 0,0261 & 0,4867 & 2,58 \\
\hline $\begin{array}{l}\text { aug. } \\
10\end{array}$ & 0,0036 & $-0,0052$ & $-0,0163$ & $-0,0486$ & - 0,0063 & 0,0079 & 0 & 0,0014 & $-0,017$ & 0,0063 & $-0,1$ & 0,1 & 0,77 & 0,0041 & $-0,139$ & 0,23 \\
\hline $\begin{array}{l}\text { sep. } \\
10\end{array}$ & 0,0419 & 0,006 & $-0,0065$ & 0,0839 & 0,0601 & 0,0127 & 0 & 0 & 0,017 & $\begin{array}{l}- \\
0,0171\end{array}$ & $-0,1$ & 0 & $\begin{array}{l}- \\
0,88\end{array}$ & 0,0018 & 0 & 0,56 \\
\hline $\begin{array}{l}\text { oct. } \\
10\end{array}$ & $-0,0014$ & 0,0036 & $-0,0583$ & 0,0362 & 0,0226 & $\begin{array}{l}- \\
0,0361\end{array}$ & $\begin{array}{l}- \\
0,0416\end{array}$ & 0,0014 & 0,0152 & 0,0917 & 0 & 0,1 & 0,73 & 0,001 & 0 & 0,55 \\
\hline $\begin{array}{l}\text { nov. } \\
10\end{array}$ & $-0,0342$ & 0,0031 & 0,0198 & $-0,0023$ & 0,0263 & 0,0164 & 0 & 0,0014 & 0,0068 & 0,0316 & $-0,1$ & 0,16 & $-0,9$ & 0,0014 & 0 & 0,52 \\
\hline $\begin{array}{l}\text { dec. } \\
10 \\
\end{array}$ & 0,0383 & $-0,0001$ & 0,0325 & 0,0633 & 0,0651 & 0,0209 & 0 & 0,0028 & 0,0008 & 0,0639 & $\begin{array}{l}- \\
0,22 \\
\end{array}$ & $-6,87$ & 6,87 & 0,0022 & $\begin{array}{l}- \\
0,1598\end{array}$ & 0,53 \\
\hline
\end{tabular}




\section{Available online at www.managementjournal.info}

Annexure 2: The sensitivity coefficients resulted through method (A)

\begin{tabular}{|c|c|c|c|c|c|c|c|c|c|c|c|c|c|c|c|}
\hline b1 & $\mathrm{b} 2$ & b3 & $\mathrm{b} 4$ & b5 & b6 & b7 & b8 & b9 & b10 & b11 & b12 & b13 & b14 & b15 & b16 \\
\hline 106,632 & $-142,091$ & $-28,550$ & 82,046 & 121,580 & $-10,308$ & $-62,856$ & $-11,739$ & $-14,747$ & $\begin{array}{l}- \\
12,409\end{array}$ & 0,155 & $-0,693$ & 0,026 & $-217,926$ & 13,443 & $-0,544$ \\
\hline 90,149 & 180,587 & $-38,548$ & 33,144 & $-35,233$ & 48,998 & 46,618 & $-8,309$ & $-33,620$ & 7,520 & 0,094 & $-0,307$ & 0,206 & $-733,467$ & 0,150 & 8,240 \\
\hline 178,311 & 194,233 & 90,652 & 65,752 & 180,404 & 69,427 & $-8,409$ & 51,869 & 3,289 & 28,678 & 3,312 & $-1,375$ & 1,912 & $-131,518$ & $-1,177$ & 3,391 \\
\hline 63,717 & $-144,859$ & 20,670 & 53,502 & $-78,634$ & 65,026 & 103,632 & 5,223 & $-17,315$ & $-8,789$ & 0,660 & 0,507 & 0,668 & $-843,111$ & $-4,189$ & 13,588 \\
\hline 78,243 & 38,962 & $-17,401$ & $-35,912$ & 50,845 & 5,375 & 114,551 & $-23,318$ & $-24,881$ & $-7,479$ & 0,201 & 0,518 & 0,020 & $-547,051$ & $-5,605$ & 8,420 \\
\hline$-42,199$ & $-239,438$ & $-53,609$ & 38,019 & 36,140 & $-42,606$ & $-73,267$ & 1,453 & 57,875 & 15,711 & 1,005 & $-0,265$ & 0,877 & $-840,642$ & $-3,661$ & 10,981 \\
\hline 120,261 & 67,497 & $-55,097$ & $-0,026$ & 8,264 & $-6,513$ & $-57,461$ & 3,485 & $-30,273$ & 13,769 & $\overline{0}, 160$ & 0,027 & 0,050 & $-319,164$ & $-0,704$ & 4,048 \\
\hline$-74,288$ & $1.147,465$ & 72,925 & 502,294 & 123,143 & 151,815 & 344,009 & 9,834 & 0,420 & 38,174 & 1,158 & 0,349 & 2,690 & $-997,890$ & 43,700 & $-3,743$ \\
\hline 163,066 & 135,796 & $-50,131$ & $-43,653$ & 88,360 & 8,129 & 121,628 & 48,422 & $-16,232$ & $\begin{array}{l}- \\
17,981\end{array}$ & 0,508 & $-1,523$ & 0,695 & $-632,915$ & 4,575 & 4,455 \\
\hline 97,420 & 39,585 & $\begin{array}{l}- \\
115,354\end{array}$ & 10,288 & $-69,372$ & 53,721 & 168,174 & $-19,797$ & 27,300 & 3,771 & 0,116 & 0,068 & 0,262 & $-2,751$ & 13,906 & $-6,112$ \\
\hline 115,669 & 28,592 & $-2,271$ & 124,938 & $\begin{array}{l}- \\
122,165\end{array}$ & 106,445 & $\begin{array}{l}- \\
367,942 \\
\end{array}$ & $-26,599$ & $-64,690$ & 19,073 & 0,203 & 0,540 & 0,209 & $-630,683$ & 1,286 & 11,014 \\
\hline 113,442 & 81,620 & 10,462 & $-24,388$ & 31,931 & $-23,865$ & 29,797 & 12,134 & 3,068 & 6,935 & 0,396 & $-0,031$ & 0,438 & $-177,689$ & 0,683 & 0,720 \\
\hline 142,141 & $-107,427$ & 138,208 & $-16,381$ & $-58,937$ & $-30,972$ & $-43,261$ & $-15,041$ & 23,049 & 57,569 & 0,071 & 2,759 & 0,300 & $-525,341$ & $\overline{15,023}$ & 10,623 \\
\hline 84,580 & 88,834 & $\begin{array}{l}- \\
199,866 \\
\end{array}$ & $\begin{array}{l}- \\
125,065 \\
\end{array}$ & $-31,465$ & $-70,936$ & 51,554 & $-25,044$ & 20,750 & $-4,972$ & 1,812 & $-1,033$ & 1,808 & $-268,266$ & $\begin{array}{l} \\
10,830 \\
\end{array}$ & 6,827 \\
\hline 195,149 & 6,045 & 125,710 & 115,000 & 180,265 & $-40,124$ & $-75,672$ & 23,044 & $-25,717$ & $-0,367$ & 0,114 & 2,185 & 0,357 & 569,856 & 2,759 & $-2,759$ \\
\hline 145,601 & $-86,333$ & 82,392 & 2,581 & 28,863 & 24,647 & 321,281 & $-7,762$ & $-29,865$ & $-3,868$ & 0,478 & 0,668 & 0,626 & $-509,837$ & 1,532 & 12,287 \\
\hline 161,286 & $-20,001$ & 52,268 & 49,416 & $-4,323$ & 15,090 & 234,534 & $-13,171$ & $-39,610$ & 28,441 & 0,329 & 0,181 & 0,334 & $-315,108$ & 5,597 & 5,821 \\
\hline 118,867 & $-80,337$ & 76,983 & $-67,073$ & 83,032 & 28,718 & 117,449 & $-14,590$ & $-15,418$ & $-7,718$ & 0,856 & 0,075 & 0,750 & $-395,219$ & 1,513 & 8,811 \\
\hline 151,470 & 32,500 & 12,856 & 25,545 & $-15,439$ & 24,100 & 200,515 & $-20,700$ & $-23,860$ & $-6,605$ & 0,022 & 0,485 & 0,099 & $-570,741$ & 5,132 & 8,467 \\
\hline 130,108 & 13,026 & 18,131 & $-10,673$ & 46,879 & 20,357 & 129,483 & $-13,092$ & $-33,793$ & 0,390 & 0,845 & 0,049 & 0,909 & $-541,789$ & 5,387 & 8,749 \\
\hline 24,543 & $-111,043$ & 17,307 & 75,582 & $-27,404$ & $-20,252$ & 54,691 & 3,769 & $-4,916$ & $-0,933$ & 0,106 & $-1,297$ & 0,091 & 448,895 & 9,988 & $-4,721$ \\
\hline 107,765 & 97,810 & 34,294 & 27,076 & $-27,820$ & $-11,560$ & 284,382 & 2,382 & $-20,632$ & 14,146 & 0,447 & 0,668 & 0,147 & $-33,421$ & 9,229 & $-3,299$ \\
\hline 85,510 & 114,871 & 15,257 & 121,614 & 169,008 & $-40,945$ & 382,588 & 21,262 & $-32,969$ & $-3,981$ & 1,433 & 0,859 & 1,058 & $-213,931$ & $-1,901$ & $-3,834$ \\
\hline 110,962 & $-93,161$ & 71,843 & 27,140 & $-54,646$ & $-61,101$ & $\begin{array}{l}- \\
123,093\end{array}$ & 26,837 & $-16,184$ & 40,546 & $\overline{0}, 246$ & $-0,028$ & 0,095 & 45,243 & $-2,784$ & $-0,889$ \\
\hline 87,803 & 7,809 & $-34,804$ & 127,522 & $\begin{array}{l}- \\
208,544\end{array}$ & $-88,298$ & $-68,317$ & $-0,114$ & 29,152 & 32,645 & $\overline{-}-334$ & $-0,410$ & $\overline{-}-520$ & $-376,271$ & - & 10,688 \\
\hline 80,133 & $-18,959$ & 13,242 & 43,276 & $-48,220$ & $\begin{array}{c}-46,849 \\
\end{array}$ & 212,619 & $\begin{array}{l}0,114 \\
-8,892 \\
\end{array}$ & 30,810 & 40,930 & 1,399 & $\begin{array}{r}-0,066 \\
\end{array}$ & 1,522 & $-206,120$ & 1,004 & 0,012 \\
\hline 90,795 & $-110,047$ & 152,996 & 219,041 & 174,213 & 22,950 & 180,713 & 57,064 & 36,114 & 17,206 & 1,682 & 2,151 & 1,182 & $-877,093$ & 14,048 & 6,400 \\
\hline 107,685 & 87,130 & $-78,893$ & $-89,953$ & 60,675 & 58,677 & 207,888 & 5,530 & $-46,155$ & $\begin{array}{l}- \\
15,587 \\
\end{array}$ & $\begin{array}{l}- \\
1,501\end{array}$ & $-0,010$ & 1,402 & $\begin{array}{l} \\
1.074,047\end{array}$ & 28,941 & 1,193 \\
\hline$-21,094$ & $-193,362$ & 111,327 & 231,627 & 199,393 & 189,367 & 212,266 & $-26,547$ & $-43,099$ & 40,431 & 0,187 & 0,466 & 115 & $-875,108$ & 6,201 & 5,578 \\
\hline 46,504 & $-100,328$ & 13,772 & $-25,100$ & $-41,946$ & 64,745 & $-74,413$ & $-3,865$ & $-13,347$ & $-0,952$ & 1,345 & 0,229 & 0,951 & 417,757 & 11,127 & $-6,929$ \\
\hline 82,964 & 17,536 & 42,605 & 54,333 & 58,091 & $-29,499$ & $-18,709$ & $-24,959$ & 21,440 & 56,688 & 0,090 & 0,860 & 0,441 & $-209,160$ & 2,662 & $-0,568$ \\
\hline 46,843 & $-175,666$ & 10,377 & 18,386 & $-63,631$ & 0,203 & 120,869 & $-19,805$ & $-13,846$ & 27,228 & 0,117 & 0,211 & 0,144 & 425,122 & $-3,898$ & 2,101 \\
\hline 57,426 & $-128,875$ & $-56,251$ & 71,753 & $-80,622$ & $\begin{array}{l}- \\
110,243\end{array}$ & 181,170 & 12,011 & 42,597 & 13,400 & 0,144 & 0,462 & 0,137 & 139,055 & 0,470 & $-3,897$ \\
\hline 139,598 & $-243,554$ & $-42,477$ & $-87,127$ & $-29,742$ & $-27,374$ & 4,104 & $-26,608$ & 64,122 & 13,587 & 1,997 & $-0,884$ & 1,426 & $2.066,948$ & 54,412 & 44,563 \\
\hline$-65,372$ & $-401,876$ & 37,487 & 380,290 & $-32,655$ & 394,511 & 278,591 & 0,189 & $-88,799$ & 38,911 & 3,009 & 12,678 & 4,041 & $1.570,406$ & 19,355 & 32,245 \\
\hline 64,747 & $-86,384$ & $-20,490$ & $\begin{array}{l}- \\
101,258\end{array}$ & 63,775 & 22,347 & 275,232 & $-28,855$ & 13,239 & 2,255 & $\begin{array}{l}-078 \\
\end{array}$ & 0,500 & 0,704 & $1.160,102$ & 0,132 & 10,224 \\
\hline 32,990 & 12,588 & $-67,528$ & $-6,326$ & 70,659 & $-63,061$ & 115,844 & $-15,765$ & $-43,852$ & 3,191 & $\overline{0}, 260$ & 0,888 & $\overline{0}, 468$ & $\begin{array}{l}- \\
1.238,156\end{array}$ & 10,701 & 5,919 \\
\hline 72,813 & $-56,108$ & $-14,276$ & $-24,761$ & $-64,428$ & $-61,522$ & 206,439 & 41,576 & 21,579 & 15,442 & 0,257 & 0,202 & 0,064 & $-449,939$ & $\begin{array}{l}- \\
10,267\end{array}$ & 6,160 \\
\hline 62,037 & $-321,752$ & 64,987 & 130,782 & 137,449 & 50,180 & 321,625 & 33,811 & $-88,828$ & 21,175 & 1,870 & 0,210 & 1,401 & 537,418 & 21,397 & 11,007 \\
\hline 83,578 & 52,217 & 20,355 & $-49,385$ & 6,131 & 50,331 & 262,037 & $-7,700$ & $-20,897$ & 17,075 & 1,435 & $-1,764$ & 1,074 & $-210,304$ & 18,307 & 10,628 \\
\hline 39,938 & $-17,862$ & 212,509 & 6,226 & 123,922 & 180,563 & $-69,328$ & $-9,782$ & $-2,464$ & 47,893 & 2,902 & $-1,183$ & 2,219 & 905,303 & 13,196 & 10,495 \\
\hline 79,230 & 33,342 & 13,639 & 47,255 & $-79,671$ & 19,062 & & 13,113 & $-71,228$ & 15,137 & 0,710 & 1,824 & 0,398 & $-393,838$ & $-3,179$ & 6,525 \\
\hline
\end{tabular}


Available online at www.managementjournal.info

\begin{tabular}{|c|c|c|c|c|c|c|c|c|c|c|c|c|c|c|c|}
\hline & & & & & & 207,097 & & & & & & & & & \\
\hline 46,055 & 32,770 & $-39,676$ & 112,786 & $-55,587$ & 83,532 & 52,585 & 3,106 & $-19,953$ & $-1,351$ & $\overline{0}, 935$ & 0,642 & $\overline{-}, 015$ & $\begin{array}{l}- \\
1.317,785\end{array}$ & 4,079 & 13,390 \\
\hline 84,862 & 16,066 & $-1,191$ & 45,491 & $-9,020$ & 7,370 & 96,473 & $-1,194$ & $-47,394$ & 10,423 & 2,798 & 0,127 & 1,368 & $-612,629$ & 13,756 & $-5,891$ \\
\hline 86,558 & 46,620 & 100,353 & $-93,083$ & 25,130 & 43,495 & 88,882 & $-8,776$ & 38,994 & 21,623 & 0,186 & $-1,213$ & 0,526 & $-379,899$ & $-0,218$ & 1,533 \\
\hline 144,684 & 150,804 & 335,449 & 190,195 & 137,855 & $-32,632$ & $-42,985$ & 119,762 & $-15,473$ & 29,515 & 0,198 & 3,664 & 0,557 & 108,487 & 16,105 & $\begin{array}{l}- \\
12,223\end{array}$ \\
\hline 95,291 & 231,133 & 108,550 & 73,746 & 196,304 & 21,218 & $-44,827$ & 15,202 & $-42,130$ & 10,329 & 0,706 & $-2,209$ & 0,333 & $-644,484$ & $-1,291$ & 6,878 \\
\hline$-9,116$ & $-260,485$ & $-26,448$ & 213,756 & 154,179 & 129,419 & 45,934 & $-18,789$ & $-21,591$ & 15,756 & 0,804 & $-1,392$ & 0,658 & $-477,211$ & $-0,056$ & 2,460 \\
\hline 59,120 & 54,540 & 99,562 & 134,780 & 102,010 & $-30,929$ & $-6,156$ & $-12,181$ & 7,254 & 15,398 & 0,340 & 1,131 & 0,407 & $-448,509$ & $-3,359$ & 3,367 \\
\hline 82,208 & 130,346 & $\overline{141,071}$ & $-42,378$ & 101,154 & 19,509 & $-42,485$ & $-6,800$ & $-83,702$ & $-3,524$ & 1,222 & $-1,421$ & 0,702 & $-449,809$ & 6,504 & 2,680 \\
\hline$-75,464$ & $-234,186$ & 7,531 & 31,917 & 191,622 & $-73,979$ & 289,523 & 5,909 & $-8,123$ & $-3,593$ & 0,371 & 0,261 & 0,633 & $-598,678$ & 3,470 & 9,054 \\
\hline 77,315 & $-174,203$ & 23,711 & $-0,947$ & 111,819 & 36,152 & 150,081 & $-8,511$ & $-21,274$ & 23,694 & 0,664 & 0,086 & 0,627 & $-111,998$ & $-1,118$ & 0,326 \\
\hline 198,773 & $-111,837$ & 19,343 & 147,517 & 30,051 & 313,431 & $-19,374$ & $-4,246$ & $-2,585$ & 16,050 & 3,106 & 0,528 & 3,948 & 476,925 & 43,048 & $\begin{array}{l}- \\
14,610\end{array}$ \\
\hline 152,351 & 229,098 & 306,906 & 8,003 & $-88,278$ & 181,259 & $-10,372$ & 28,571 & $-33,556$ & 31,366 & 2,067 & $-1,448$ & 0,577 & $-589,429$ & $-9,883$ & 9,978 \\
\hline 232,992 & $-19,735$ & 37,692 & 333,603 & 23,893 & 249,712 & $-64,304$ & $-22,440$ & 130,742 & 80,502 & 2,471 & $-1,556$ & 2,872 & 984,763 & 34,022 & $\begin{array}{l}- \\
30,026\end{array}$ \\
\hline$-69,357$ & $-195,493$ & 57,265 & 240,451 & 62,856 & $-86,346$ & 258,625 & 31,418 & $-22,038$ & 7,003 & 2,143 & 4,143 & 1,254 & $-960,588$ & 24,099 & 0,871 \\
\hline 73,540 & 243,667 & $-16,266$ & 8,013 & $-19,978$ & $-15,891$ & $-6,348$ & $-7,833$ & 10,663 & 28,493 & 0,093 & 0,078 & 0,064 & $-781,167$ & $-1,701$ & 4,377 \\
\hline 94,549 & 307,022 & 139,431 & $\overline{101,910}$ & 106,359 & $-15,718$ & 437,848 & 20,640 & $-28,214$ & 5,707 & 1,666 & $-0,908$ & 1,061 & - $1.166,142$ & 6,345 & 1,862 \\
\hline 99,554 & 31,085 & 40,901 & 150,770 & 109,641 & 33,400 & $-1,471$ & 62,883 & $-15,546$ & 32,938 & 2,273 & $-0,068$ & 1,754 & $-371,048$ & $-1,851$ & 9,321 \\
\hline 56,042 & $-81,107$ & $-36,939$ & $-88,575$ & 18,201 & 51,473 & 174,527 & $-2,090$ & 7,330 & 20,793 & 1,018 & $-0,460$ & 0,843 & $-114,554$ & 4,438 & $-8,357$ \\
\hline
\end{tabular}

Annexure 3: Total variance explained in a cumulative way by the chosen number of factors

\begin{tabular}{|c|c|c|c|c|c|c|}
\hline \multirow[b]{2}{*}{ Component } & \multicolumn{3}{|c|}{ Initial eigenvalues } & \multicolumn{3}{|c|}{ Extraction sums of squared loadings } \\
\hline & Total & $\%$ of variance & Cumulative \% & Total & $\%$ of variance & Cumulative \% \\
\hline 1 & 4,002 & 25,015 & 25,015 & 4,002 & 25,015 & 25,015 \\
\hline 2 & 2,324 & 14,527 & 39,542 & 2,324 & 14,527 & 39,542 \\
\hline 3 & 2,212 & 13,827 & 53,369 & 2,212 & 13,827 & 53,369 \\
\hline 4 & 1,283 & 8,020 & 61,390 & 1,283 & 8,020 & 61,390 \\
\hline 5 & 1,135 & 7,097 & 68,486 & 1,135 & 7,097 & 68,486 \\
\hline 6 &, 918 & 5,736 & 74,222 & & & \\
\hline 7 &, 825 & 5,154 & 79,377 & & & \\
\hline 8 &, 693 & 4,333 & 83,710 & & & \\
\hline 9 &, 666 & 4,160 & 87,870 & & & \\
\hline 10 &, 554 & 3,464 & 91,334 & & & \\
\hline 11 &, 417 & 2,605 & 93,939 & & & \\
\hline 12 &, 330 & 2,062 & 96,001 & & & \\
\hline 13 &, 256 & 1,599 & 97,600 & & & \\
\hline 14 &, 191 & 1,194 & 98,794 & & & \\
\hline 15 &, 107 & ,669 & 99,463 & & & \\
\hline 16 &, 086 &, 537 & 100,000 & & & \\
\hline
\end{tabular}

Annexure 4:Factor loadings values given by SPSS

\begin{tabular}{|l|c|c|c|c|c|}
\hline & \multicolumn{3}{|c|}{ Component } \\
\hline & $\mathbf{1}$ & $\mathbf{2}$ & $\mathbf{3}$ & $\mathbf{4}$ \\
\hline SP500 & 0,896 & $-0,039$ & 0,035 & $-0,134$ \\
\hline BESE & 0,856 & $-0,120$ & 0,046 & $-0,171$ \\
\hline RONUSD & 0,854 & $-0,123$ & 0,086 & $-0,051$ & $-0,105$ \\
\hline RONEUR & $-0,748$ & $-0,018$ & $-0,095$ & $-0,334$ & $-0,257$ \\
\hline OP & $-0,622$ & 0,253 & $-0,222$ & $-0,007$ & $-0,059$ \\
\hline RCG & 0,578 & 0,185 & $-0,024$ & $-0,092$ & $-0,192$ \\
\hline
\end{tabular}


Available online at www.managementjournal.info

\begin{tabular}{|l|c|c|c|c|c|}
\hline IPC & 0,028 & 0,827 & $-0,103$ & 0,155 & $-0,121$ \\
\hline AIR & $-0,140$ & 0,783 & $-0,035$ & $-0,148$ & 0,234 \\
\hline RIR & $-0,071$ & $-0,015$ & $-0,918$ & $-0,095$ & 0,051 \\
\hline DP & 0,150 & $-0,009$ & 0,903 & 0,112 & 0,053 \\
\hline MIR & $-0,139$ & $-0,171$ & $-0,500$ & 0,472 & 0,179 \\
\hline M1 & $-0,038$ & $-0,222$ & 0,464 & 0,398 & 0,206 \\
\hline PIB & $-0,034$ & 0,231 & 0,045 & 0,715 & $-0,190$ \\
\hline TSIR & 0,048 & $-0,189$ & 0,318 & 0,505 & 0,066 \\
\hline IPI & 0,013 & 0,089 & 0,012 & $-0,032$ & 0,947 \\
\hline
\end{tabular}

Annexure 5: Factor scores values obtained in working stage 4

\begin{tabular}{|c|c|c|c|c|}
\hline Factor score total F1 & Factor score total F2 & Factor score total F3 & Factor score total F4 & Factor score total F5 \\
\hline 0,1641 & 0,5641 & 14,7763 & 0,0000 & $-0,1298$ \\
\hline 0,2370 & 0,4336 & 10,0264 & 0,9090 & $-0,0817$ \\
\hline$-0,1802$ & 0,1446 & 9,6422 & 0,0000 & $-0,0233$ \\
\hline$-0,1474$ & 1,9675 & 11,2672 & $-2,5351$ & 0,0039 \\
\hline 0,1183 & 0,1747 & 10,9430 & 1,0605 & 0,1193 \\
\hline 0,0480 & 0,1600 & 8,7467 & 0,0000 & $-0,0704$ \\
\hline 0,2101 & 0,9010 & 14,7340 & $-0,0006$ & 0,0956 \\
\hline 0,0456 & $-0,0378$ & 14,3590 & 2,7270 & $-0,0184$ \\
\hline 0,0768 & 0,5394 & 9,1804 & 0,0000 & $-0,0328$ \\
\hline$-0,1464$ & 0,9357 & 14,6209 & $-0,0109$ & $-0,0058$ \\
\hline 0,0950 & 1,0893 & 14,4754 & 0,0000 & 0,0549 \\
\hline 0,0693 & 0,4513 & 14,7287 & 0,0000 & 0,0345 \\
\hline 0,1912 & 1,2256 & 14,3401 & $-0,0013$ & $-0,0085$ \\
\hline 0,0546 & $-0,2034$ & 14,2803 & 0,0000 & $-0,1121$ \\
\hline 0,0577 & 0,0421 & 12,8355 & 0,0000 & $-0,0171$ \\
\hline 0,0659 & 0,3683 & 13,2327 & $-0,0045$ & 0,0506 \\
\hline$-0,1005$ & 0,5450 & 13,0762 & 0,0000 & 0,1040 \\
\hline 0,0067 & $-0,0445$ & 12,2836 & 0,0000 & $-0,1227$ \\
\hline 0,0614 & 0,0924 & 12,0906 & $-0,0066$ & 0,1361 \\
\hline$-0,0449$ & $-0,2946$ & 11,5723 & 0,0000 & $-0,0256$ \\
\hline 0,0133 & 0,0410 & 10,9615 & 0,0000 & $-0,0230$ \\
\hline 0,1173 & 0,1845 & 10,8268 & 0,0233 & $-0,0248$ \\
\hline 0,0326 & 1,2141 & 11,0035 & 0,0000 & 0,0393 \\
\hline 0,0054 & 0,6705 & 10,2981 & 3,3381 & 0,0578 \\
\hline 0,1328 & $-0,3776$ & $-1,5744$ & 0,3068 & $-0,0205$ \\
\hline 0,0242 & $-0,5120$ & $-1,6067$ & 0,4949 & $-0,1298$ \\
\hline 0,0704 & 0,0620 & $-2,7726$ & 0,0909 & 0,0144 \\
\hline 0,1361 & 1,0176 & $-3,0892$ & $-0,0189$ & 0,0644 \\
\hline 0,1053 & 0,9007 & $-3,2584$ & $-0,0808$ & 0,0629 \\
\hline 0,1530 & 0,1265 & $-2,8798$ & $-0,0656$ & $-0,0329$ \\
\hline 0,0370 & 0,2636 & $-1,7411$ & $-0,0045$ & 0,0439 \\
\hline 0,0170 & 0,7851 & $-0,4829$ & $-0,0050$ & $-0,0142$ \\
\hline 0,0170 & 1,2145 & 0,1349 & 0,1364 & $-0,0132$ \\
\hline 0,1665 & 1,0621 & $-1,3183$ & $-0,2954$ & $-0,0879$ \\
\hline$-0,2081$ & 0,8394 & $-1,3971$ & $-0,1919$ & 0,0904 \\
\hline 0,0261 & 0,5778 & $-1,9336$ & 0,1768 & $-0,0045$ \\
\hline$-0,3955$ & 1,2604 & $-2,9592$ & 0,1935 & $-0,1099$ \\
\hline 0,0564 & 0,5417 & $-2,8037$ & 0,0202 & $-0,2020$ \\
\hline$-0,0165$ & 0,5018 & $-2,9886$ & 0,1010 & 0,0489 \\
\hline 0,2177 & 0,4701 & $-4,0146$ & $-0,3173$ & $-0,0059$ \\
\hline 0,1057 & 0,3166 & $-4,2248$ & $-0,4495$ & 0,0067 \\
\hline$-0,2870$ & 0,2543 & $-4,0417$ & $-0,3636$ & 0,0083 \\
\hline$-0,1374$ & 0,6270 & $-5,4301$ & $-0,2255$ & 0,0008 \\
\hline$-0,1104$ & $-0,2363$ & $-6,7058$ & $-0,6212$ & 0,0107 \\
\hline$-0,6617$ & 0,3561 & $-6,2396$ & $-0,0505$ & 0,0017 \\
\hline$-0,8963$ & 1,1061 & $-9,5675$ & $-0,1855$ & 0,0057 \\
\hline$-0,3611$ & 0,1371 & $-12,1880$ & $-0,4949$ & 0,0129 \\
\hline$-0,0516$ & 0,2045 & $-12,3639$ & $-0,6262$ & 0,0087 \\
\hline$-0,5248$ & 1,8402 & $-10,9496$ & $-0,7172$ & 0,0150 \\
\hline$-0,2349$ & 0,7244 & $-8,4494$ & $-0,0101$ & $-0,0047$ \\
\hline 0,3296 & 0,2847 & $-8,6667$ & 0,0101 & $-0,0254$ \\
\hline 0,4896 & 0,0367 & $-9,1523$ & $-0,1987$ & $-0,0163$ \\
\hline 0,2690 & $-0,1200$ & $-8,6864$ & $-0,0505$ & 0,0409 \\
\hline$-0,0607$ & 0,0329 & $-9,0873$ & 0,0202 & 0,0047 \\
\hline 0,2825 & $-0,2485$ & $-8,8604$ & $-0,3040$ & 0,0039 \\
\hline 0,1464 & $-0,1725$ & $-7,9400$ & $-0,2373$ & 0,0170 \\
\hline
\end{tabular}


Available online at www.managementjournal.info

\begin{tabular}{|c|c|c|c|c|}
\hline 0,1826 & 0,3524 & $-7,8604$ & 0,0202 & $-0,0092$ \\
\hline$-0,0189$ & 0,3927 & $-7,5893$ & 0,0292 & 0,0000 \\
\hline 0,0921 & 0,6084 & $-7,5269$ & 0,0000 & 0,0107 \\
\hline$-0,0898$ & 0,2900 & $-7,1043$ & $-0,6060$ & 0,0061 \\
\hline 0,1715 & 2,7119 & $-5,5521$ & $-0,6832$ & 0,0158 \\
\hline 0,0407 & $-0,3578$ & $-3,2924$ & $-0,2980$ & $-0,0023$ \\
\hline 0,2636 & $-0,0088$ & $-1,9149$ & 0,1717 & 0,0309 \\
\hline$-0,0227$ & 0,1919 & $-1,3508$ & 0,5053 & $-0,0014$ \\
\hline$-0,4099$ & $-0,0105$ & $-1,7319$ & 0,3333 & $-0,0116$ \\
\hline$-0,1745$ & 0,1443 & 0,3746 & 0,1566 & 0,0044 \\
\hline 0,1970 & 2,7350 & 0,4545 & 0,0832 & 0,0051 \\
\hline$-0,0268$ & 0,1025 & 0,6209 & 0,0505 & $-0,0161$ \\
\hline 0,1536 & 0,5077 & 0,7234 & 0,0000 & 0,0161 \\
\hline 0,1450 & 0,4980 & 0,6527 & 0,0208 & 0,0144 \\
\hline$-0,0523$ & 0,4689 & 0,7428 & 0,0808 & $-0,0064$ \\
\hline 0,1578 & 0,3558 & $-6,4970$ & $-3,4694$ & $-0,0008$ \\
\hline
\end{tabular}

Annexure 6: Sensitivity coefficients obtained in working stage

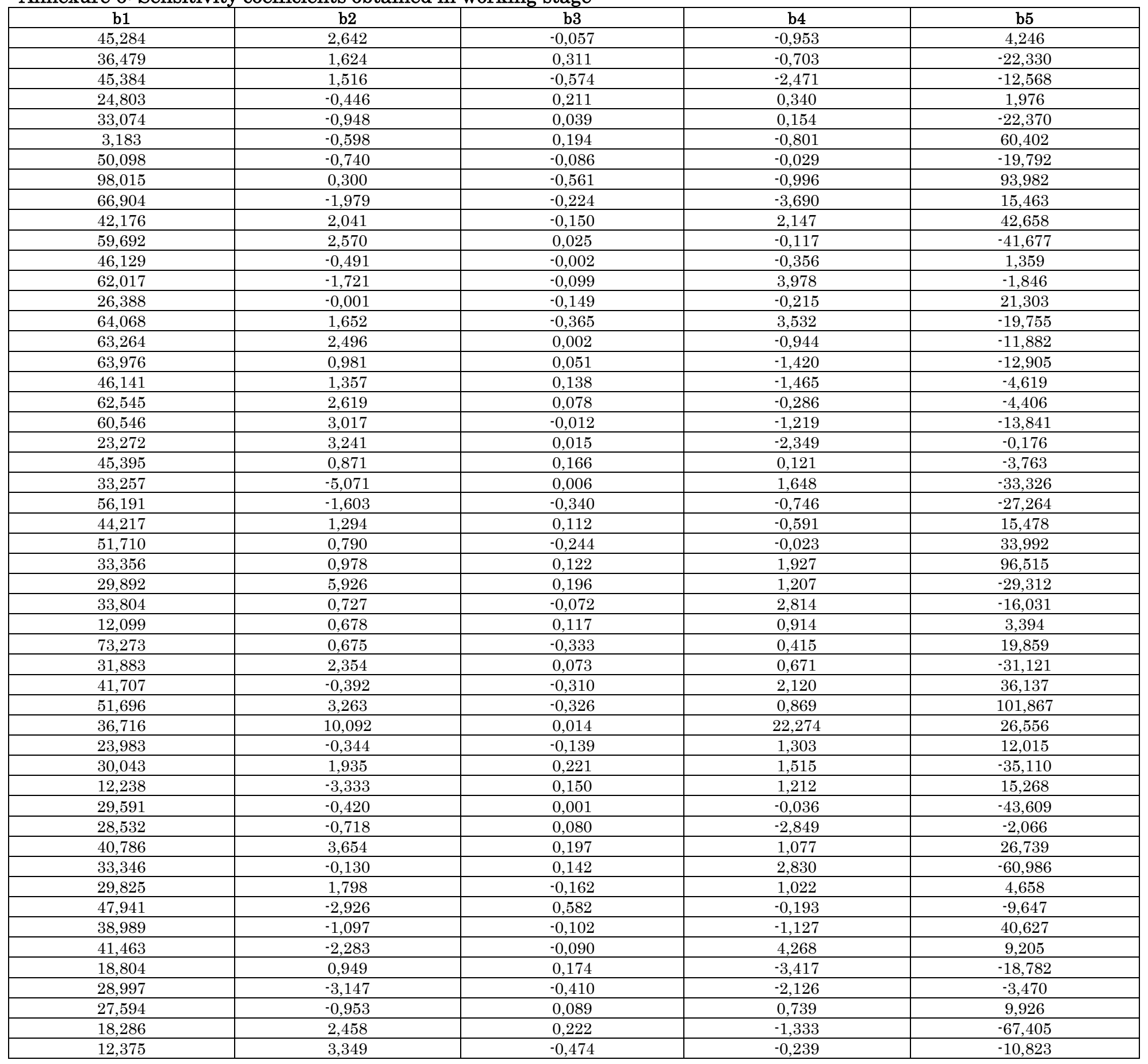


Available online at www.managementjournal.info

\begin{tabular}{|c|c|c|c|c|}
\hline 29,737 & $-2,106$ & 0,065 & 0,322 & $-19,763$ \\
\hline 70,693 & 5,100 & $-0,579$ & 2,340 & $\begin{array}{l}64,331 \\
\end{array}$ \\
\hline 64,767 & 0,496 & 0,454 & $-0,939$ & $-14,970$ \\
\hline 68,433 & $-2,195$ & $-0,473$ & $-0,880$ & $-119,881$ \\
\hline 30,931 & 4,053 & 0,234 & 6,434 & 25,050 \\
\hline 31,102 & $-0,414$ & $-0,090$ & $-0,460$ & 15,960 \\
\hline 39,198 & $-1,574$ & 0,193 & $-0,590$ & $-7,987$ \\
\hline 7,696 & 0,398 & $-0,071$ & $-0,241$ & $-29,361$ \\
\hline 24,515 & $-5,149$ & 0,088 & 0,392 & 11,554 \\
\hline
\end{tabular}

